\title{
Perturbed functional networks in Alzheimer's Disease reveal opposing roles for TGIF and EGR3
}

Saranya Canchi ${ }^{1,2}$, Balaji Raao ${ }^{1}$, Deborah Masliah ${ }^{1}$, Sara Brin Rosenthal ${ }^{3}$, Roman Sasik $^{3}$, Kathleen M. Fisch ${ }^{3}$, Philip De Jager ${ }^{4}$, David A. Bennett ${ }^{5}$, Robert A. Rissman ${ }^{1,2}$

${ }^{1}$ Department of Neurosciences, University of California, San Diego, La Jolla, CA

${ }^{2}$ Veterans Affairs San Diego Healthcare System, San Diego, CA,

${ }^{3}$ Center for Computational Biology \& Bioinformatics, Department of Medicine, University of California, San Diego

${ }^{4}$ Center for Translational \& Computational Neuroimmunology, Department of Neurology, Columbia University Medical Center, New York,

${ }^{5}$ Rush Alzheimer's Disease Center, Rush University Medical Center, Chicago, IL 


\section{Abstract}

While Alzheimer's disease (AD) is the most prevalent cause of dementia, complex combinations of the underlying pathologies have led to evolved concepts in clinical and neuropathological criteria in the past decade. Pathological AD can be decomposed into subsets of individuals with significantly different antemortem cognitive decline rates. Using transcriptome as a proxy for functional state, we preselected 414 expression profiles of clinically and neuropathologically confirmed AD subjects and age matched nondemented controls sampled from a large community based neuropathological study. By combining brain tissue specific protein interactome with gene network, we identify functionally distinct composite clusters of genes which reveal extensive changes in expression levels in AD. The average global expression for clusters corresponding to synaptic transmission, metabolism, cell cycle, survival and immune response were downregulated while the upregulated cluster had a large set of uncharacterized pathways and processes that may constitute an AD specific phenotypic signature. We identified four master regulators across all clusters of differentially expressed genes by enrichment analysis including TGIF1 and EGR3. These transcription factors have previously not been associated with $A D$ and were validated in brain tissue samples from an independent $A D$ cohort. We identify TGIF1, a transcriptional repressor as being neuroprotective in AD by activating co-repressors regulating genes critical for DNA repair, maintaining homeostasis and arresting cell cycle. In addition, we show that loss of EGR3 regulation, mediates synaptic deficits by targeting the synaptic vesicle cycle. Collectively, our results highlight the utility of integrating protein interactions with gene perturbations to generate a comprehensive framework for characterizing the alterations in molecular network as applied to $A D$. 


\section{Introduction}

Increase in aging population with improved longevity reinforces the urgency for prevention and treatment of progressive neurodegenerative diseases including Alzheimer's disease $(A D)$, the most common cause of dementia ${ }^{11,41}$. While, the predominant pathology of $A D$ is accumulation of neuritic $\beta$-amyloid $(A \beta)$ plaques and neurofibrillary tangles containing phosphorylated tau protein, co-occurrence of other neuropathological features is increasingly recognized to be a frequent event in brains of demented patients ${ }^{1,11}$. These changes including but not limited to inflammation, neuronal and synaptic loss, problems with blood circulation, and atrophy correlate with clinical symptoms of cognitive decline and have led to changes in diagnostic criteria during the last decade $6,41,78$.

Multiple causal factors underlie the complexity of sporadic AD. Primary risk factors include age, gender and family history ${ }^{41}$. The presence of elevated blood cholesterol, diabetes, depression, multiple lifestyle and dietary factors are also associated with increased risk of $A D$ dementia, although not necessarily with $A D$ pathology ${ }^{6}$. Genetic mutations in amyloid precursor protein (APP), presenilin 1 (PSEN1), and presenilin 2 (PSEN2) associated with autosomal dominant $A D$ were critical in identifying pathogenic mechanisms associated with $A \beta$ accumulation ${ }^{5,83}$. While many of the GWAS identified genes including the $\varepsilon 4$ allele of apolipoprotein $E(A P O E)$ have implications of $A \beta$ / tau processing, it is interesting to note that majority of the risk loci associate strongly with pathways involved in inflammation, lipid metabolism and endocytosis, which may partially explain the association of non-genetic risk factors ${ }^{46,99}$. Translation of molecular insights into predictive screening and diagnosis is important since clinical diagnosis of $A D$ is difficult and often imprecise ${ }^{41}$. This is complicated by the fact that genetic mutations explain only a small proportion of autosomal dominant $A D$ and presence of $A P O E \varepsilon 4$ is 
not sufficient to cause $A D$ 6,11, 41 . In addition, considering the variability in the rate of cognitive decline between individuals, transcriptomic changes at preclinical, prodromal and dementia stages of $A D$ may be distinct and warrant subject selection refinement ${ }^{11}$, 95.

In this study, we selected 414 clinically and neuropathologically confirmed AD subjects and cognitively normal age-matched controls, all sampled from a large well characterized community based neuropathological study 6,68 . Integration of gene perturbations with protein interactions is a powerful method to identify genes causal of a phenotype that are functionally cohesive, physically interact and share coherent biological pathways ${ }^{66}$. We characterize the molecular network dysregulation in AD relative to controls by integrating global gene expression profiles with a pre-calculated brain tissue specific protein-protein interactome ${ }^{34}$. Community detection applications to the human brain transcriptome have revealed intrinsic topological organization of functional co-expressed modules, they generally consider single interaction data 46, 9966 . By integrating the transcriptomic changes with protein interaction networks, we identify functional composite clusters by implementing the Louvain algorithm. The distinct gene clusters reveal extensive expression changes across multiple biological and cellular pathways implicated in AD along with novel candidates with less understood biological function. By applying the strategy of gene set enrichment, we identify four master transcriptional regulators across all the clusters. These include TGFB induced factor homeobox 1 (TGIF1), and early growth response 3 (EGR3), previously not associated with $A D$ and validated by protein analysis of brain tissue samples from an independent $A D$ cohort. We identify transcriptional repressor TGIF which modulates the disrupted TGF- $\beta$ signaling, as being 
neuroprotective in AD by activating co-repressors regulating genes critical for arresting cell cycle, facilitating DNA-repair and restoring homeostasis 64,89 . We show loss of regulation of EGR3 which is crucial for short term memory, to mediate synaptic deficits by targeting the synaptic vesicle cycle ${ }^{69,78}$.

\section{Results and Discussion}

2.1 Refined $A D$ phenotype reveals perturbation in the transcriptomic landscape

After adjusting for covariates and multiple testing, total of 1722 genes were significantly differentially expressed in AD compared to age-matched non-demented controls (NDC) and $57 \%$ of those genes were downregulated (Figure 1A, Supplementary Table S1). Gene Set Enrichment Analysis (GSEA) ${ }^{82}$ revealed functional enrichment of specific biological processes (GO) and molecular pathways (KEGG) underlying these genes. A total of 453 upregulated and 113 downregulated MSigDB gene sets ${ }^{82}$ were identified at $5 \%$ FDR. Among the GO terms enriched, those related to neural development, gliogenesis, metabolism and localization of proteins and extracellular structure organization were upregulated while those related to synaptic transmission, mitochondrial and metabolic processes as well as extracellular transport were downregulated (Supplementary Tables S2, S3). These results are consistent with previous findings of multiple studies associating AD pathophysiology to genetic perturbation and demonstrate the complexity of the disease $11,46,68,95,99$.

A total of 133 differentially expressed genes were also mitochondrial genes, defined as mitochondrially encoded genes from MitoCarta $2.0^{16}$ (Figure 1B) (Supplementary Table S4). Among these are nuclear-encoded genes for oxidative phosphorylation (OXPHOS) 
(Figure 1C). These include NADH ubiquinone oxidoreductase core subunits S1 $(N D U F S 1, \mathrm{PEP}=2.4 \mathrm{e}-02)$, A5 (NDUFA5, PEP $=8.0 \mathrm{e}-05), \mathrm{A} 10($ NDUFA10, $\mathrm{PEP}=1.3 \mathrm{e}-$ 02) and B5 (NDUFB5, PEP $=2.4 \mathrm{e}-02)$, all part of complex I involved in transfer of electrons to the respiratory chain. Reduced expression of complex $\mathrm{V}$ genes including ATPase inhibitory factor I $($ ATPIF1, PEP $=2.4 \mathrm{e}-03)$, subunit $\mathrm{B}($ ATP5F1, PEP $=1.8 \mathrm{e}-03)$ and $\mathrm{F} 1$ alpha subunit $(A T P 5 A 1, \mathrm{PEP}=3.7 \mathrm{e}-02)$ have implications for production of ATP from ADP ${ }^{18}$. In addition, expression of eight mitochondrial ribosomal proteins subunits $(M R P)$ involved in translation of the mitochondrial-encoded OXPHOS genes are downregulated. Downregulated nuclear and mitochondrial genes encoding subunits involved in OXPHOS have been shown in the brain and blood of subjects with AD and mild cognitive impairment (MCl) compared to NDC ${ }^{25,58}$. While most mitochondrial genes were downregulated, 27 genes showed upregulation (Figure 1B). Of these, increased expression of diazepam-binding inhibitor $(D B I$, PEP $=8.9 \mathrm{e}-04)$, known for its role as mediator in corticotropin-dependent adrenal steroidogenesis and in modulation of the action of the GABA receptor has been shown to be dose dependent on $A \beta$ aggregates 57.

2.2 Aggregate network of protein and genetic interactions reveals novel gene candidates in biologically distinct clusters associated with $A D$ pathogenesis

When integrated into the GIANT brain-specific interactome ${ }^{34}$, the differentially expressed genes display distinct clustering structure (Figure 2A). These clusters were identified computationally using the Louvain modularity maximization algorithm ${ }^{88}$. This graphbased unsupervised clustering analysis does not require any explicit assumptions, and 
instead uses an iterative process to optimally partition nodes in a graph, by maximizing the number of edges within clusters, and minimizing the number of edges between clusters.

The largest connected subnetwork of 1391 differentially expressed genes partitions into 8 distinct clusters ranging in size from 2 to 373 genes. We restricted our analysis to clusters containing at least 5 genes and resulted in a subnetwork with 1382 genes. Many of these clusters are significantly up-regulated or down-regulated in AD with respect to NDC (Figure 2B, Supplementary Table S5). Two metrics were used to assess significance of up and down-regulation. The first metric was a simple binomial test, comparing the number of observed positive edges within each cluster to the number expected given the rate of positive edges within the full AD subnetwork. The second metric is the Kolmogorov-Smirnov test to check if the distribution of log fold change expression values in each cluster is significantly different than the distribution in the full AD subnetwork (Figure 2B). Of the 8 detected clusters, 5 that were enriched for up or down regulated genes are highly statistically significant (Figure 2C, Supplementary Tables S5, S6).

Overrepresentation analysis of the genes in the clusters characterized significantly enriched biological processes and molecular pathways. This revealed functionally distinct units related to broad categories of synaptic transmission, signal transduction, cell survival and viability, immune response and metabolism (Figure 3, Supplementary Table S7, Figure S1). Interestingly, the expression for clusters corresponding to synaptic 
transmission, DNA repair, immune response and metabolism were downregulated, while the cluster with overall upregulation had many uncharacterized genes (Figure 2C).

\subsubsection{Clustero - Synaptic Transmission}

Loss of neurons and synapses in the hippocampus and cerebral cortex, a characteristic of $A D$ is shown to strongly correlate with cognitive impairment, high level of $A \beta$ production along with tau oligomers ${ }^{78}$. Pathways in cluster0 were enriched for neurotransmitter related signaling (Figure 3, Supplemental Table S7, Figure S2). Expression of neuregulin$1(N R G 1, \mathrm{PEP}=6.7 \mathrm{e}-04)$ and neurexin $3(N R X N 3, \mathrm{PEP}=4.6 \mathrm{e}-03)$ which promote the formation of functional synaptic structures were downregulated ${ }^{63}$. Expression for GABAA receptors was downregulated and is comparable to recent evidence of decreased amplitude of GABA currents on examination of the electrophysiological activity of AD brains which correlated with reduced mRNA and protein expression of $\alpha 1$ and $y 2$ GABA receptor subunits in the temporal cortex 55,57. Downregulation in glutamate ionotropic receptor AMPA subunits (GRIA2, GRIA3, GRIA4) and kainate type subunits (GRIK1, GRIK2) along with SHANK2 which forms a postsynaptic scaffold for receptor complexes is consistent with the idea that excess $A \beta$ can enhance endocytic internalization of AMPA and NMDA receptors and suppress long term potentiation (LTP) in AD ${ }^{78}$. Interestingly, increased expression of lysophosphatidic acid receptor $1(L P A R 1$, PEP $=4.4 \mathrm{e}-03)$ a $\mathrm{G}$ protein coupled receptor has been shown to regulate glutamatergic and GABAergic signaling although the details are unclear ${ }^{98}$.

In addition to neurotransmitters, neurosecretory proteins and neuropeptides are well known for their role in neuronal cell communication. Reduced expression of 
neurosecretory protein VGF nerve growth factor inducible (VGF, PEP $=2.9 e-05)$ considered to be associated with synaptic plasticity and function, has recently been identified in CSF and parietal cortex of AD patients ${ }^{21,38}$. These results confirm and extend the trend to prefrontal cortex in AD. Based on the specificity of VGF to the central nervous system, it is an ideal candidate with the potential for blood based biomarker for AD. Reduced cortical corticotropin-releasing factor immunoreactivity $(C R H, P E P=2.1 e-04)$ in the face of increased hypothalamic expression) is a prominent neurochemical change in $A D$ and is shown to mediate stress induced hyperphosphorylated tau through its receptor1 (CRFR1) with antagonist reducing $A \beta$ levels in animal $A D$ models $71,100$. Decreased expression of doublecortin like kinase $1(D C L K 1, \mathrm{PEP}=7.7 \mathrm{e}-03)$ which has both microtubule-polymerizing activity and protein kinase activity likely has implications for axon trafficking deficits ${ }^{49}$. Interestingly, downregulation of dipeptidyl-peptidase 6 $(D P P 6$, PEP $=1.5 e-02)$ is associated with reduced dendritic spine density, a phenotype observed in AD brains ${ }^{56}$.

\subsubsection{Cluster1 - DNA Repair and Transcription}

Abnormal cell cycle reentry in response to accumulation of damaged DNA is hypothesized to precede AD pathogenesis ${ }^{23,94}$. Pathways in cluster1 were enriched for DNA replication and transcription (Figure 3, Supplemental Table S7, Figure S3) with approximately $15 \%$ of genes associated with cell regulated DNA repair and chromatin remodeling ${ }^{67}$. One of the highly connected genes in this cluster, minichromosome maintenance complex component $7(M C M 7$, PEP $=9.3 e-05)$, was identified as an additional AD susceptible locus in large scale GWAS study ${ }^{27}$. Expression of DNA- 
dependent protein kinase $(P R K D C, \mathrm{PEP}=9.5 \mathrm{e}-03)$ which is essential for the repair of the double strand breaks, a lethal form of DNA damage was downregulated and is comparable to protein expression observed in $A D$ brains ${ }^{17,23}$. Reduction in the base excision repair, a multistep DNA repair pathway has been detected in early stages of the disease (amnestic $\mathrm{MCl}$ ) with continued trend with progression to $A D{ }^{94}$. Reduced expression of tyrosyl-DNA phosphodiesterase 1 (TDP1, PEP $=4.0 \mathrm{e}-02)$, a DNA repair protein involved in base excision repair is a rational result ${ }^{26}$. Overexpression of DEK Proto-Oncogene $(D E K$, PEP $=4.1 \mathrm{e}-02)$ known for its role in p53 destabilization, is associated with multiple cancer phenotypes and has not been characterized in AD with potential as an early target for neuronal homeostasis ${ }^{28}$. PHD Finger Protein 19 (PHF19, PEP $=3.1 \mathrm{e}-05)$, a Polycomb-like protein is known to specifically bind to histone H3K36me3 and crucial for PRC2 recruitment to CpG islands which mainly mediate transcriptional repression ${ }^{15}$. Although its role in $A D$ remain unclear, overexpression of PHF19 as observed here has been shown to correlate positively with astrocytoma grades 53. Whether this was a consequence of cell state activity or an essential event is to be determined. Although not directly linked to AD, suppression of chromatin assembly factor I $(C H A F 1 B, P E P=2.0 \mathrm{e}-03)$ has recently been shown regulate somatic cell identity in a transcription factor-induced cell fate transition, correlated to protein levels in Down Syndrome brains and identified via whole exome sequencing to be associated with neurogenetic disorders with intellectual disability ${ }^{2,19}$. Interestingly, stathmin (STMN1, PEP $=3.3 e-02)$ known to negatively correlate with neurofibrillary tangles and highly connected to genes in this cluster is shown to mediate cell cycle regulation via MELK kinase and has been investigated as a biomarker of DNA damage in AD 61, 92. This could 
provide an important link between dysregulation of microtubule polymerization and cell cycle dynamics as seen in AD and merits further investigation.

\subsubsection{Cluster2 - Immune Response}

Immune system pathways were enriched in cluster2 (Figure 3, Supplemental Table S7, Figure S4). Several lines of evidence suggest that chronic neuroinflammation, shown to correlate with disease progression could contribute to the pathogenesis of AD $46,62,99$. The associated causal regulators including $T Y R O B P$ as described in Zhang et al ${ }^{99}$ were not significant, although pathways under the 'Fc' and 'Complement' immune and microglia modules are enriched. While the role of C-type lectin receptors (CLR), members of the pattern recognition receptor family in $A D$ are currently unclear, two functional variants of Mannose-binding lectin (MBL2), a soluble CLR are associated with AD risk ${ }^{80}$. Antagonists to $M B L 2$ have shown to facilitate favorable outcome in experimental models of traumatic brain and spinal injury suggesting a potential target for modulation of immune response 24, 33. Increased expression of the chemokine receptor $4(C X C R 4$, PEP $=3 e-0.2)$ is shown to be associated with higher levels of activated phosphorylated protein kinase $\mathrm{C}$ and with synaptic pruning in early development 65,93 . Interestingly, this was concomitant with decreased expression of $\mathrm{C} 2 \mathrm{H} 2$ zinc finger protein ( $P L A G L 1, \mathrm{PEP}=4.2 \mathrm{e}-07$ ) known to activate SOCS3, a suppressor of cytokine signaling ${ }^{76}$. Fc receptors mediated glial cell activation identified as one of the immune pathways in AD GWAS study, has been attributed in the adverse side effects associated with the failed AD immunotherapy trials reiterating the need to understand the functional roles of these receptors ${ }^{32,46}$. Decreased expression of bromodomain family member $(B R W D 1, \mathrm{PEP}=1.7 \mathrm{e}-06)$, a histone reader 
essential for B lymphopoiesis is in lieu with the observed loss of the cross talk between innate immune system of the brain and the adaptive immune system as facilitated by circulating $B$ and $T$ cells ${ }^{59,62 .}$

\subsubsection{Cluster3 - Novel Gene Candidates}

Genes from cluster3, the only cluster with an overall upregulation in the differential expression were not readily characterized. No enriched pathways were detected, and only a few marginally significant GO terms were found. Examination of this cluster revealed more uncharacterized genes than expected by chance $(p<0.05)$, suggesting genes within this cluster would be attractive candidates for follow up studies as many encode for proteins not previously characterized or associated with AD. Enriched biological processes included small GTPase mediated signal transduction (FDR = 6.21 e-05), which are known to control diverse cellular activities (Supplemental Figures, S1). Evidence suggests that dysregulation of Rho-GTPase specifically $R H O A, R A C 1$ and CDC42 mediated actin dynamics could be a key contributor to synaptic deficits observed in $A D$, yet interactions between the different signaling pathways remain unclear ${ }^{40}$. Ras homolog family members $\mathrm{C}(R H O C, \mathrm{PEP}=4.5 \mathrm{e}-02), \mathrm{D}(R H O D, \mathrm{PEP}=9.5 \mathrm{e}-03), \mathrm{G}$ $($ RHOG, PEP $=1.2 \mathrm{e}-03)$ were upregulated and increased expression of ras-associated protein rab13 $(R A B 13, \mathrm{PEP}=4.9 \mathrm{e}-03)$ paralog for $\mathrm{RAB8B}$ is consistent with the protein levels measured in $\mathrm{AD}$ brains ${ }^{40}$. ADP-ribosylation factor ( $\left.A R F 3, A R F 5\right)$ sub family of GTPase have critical roles in secretory pathway for intracellular ER-golgi trafficking and in vesicle formation ${ }^{40}$. ARF6, a paralog of $A R F 3$ was reported to be an important modulator of BACE1 sorting in early endosomes in a clathrin-independent route and 
abrogating its function led to increased $A \beta$ secretion while functions of $A R F 5$ in $A D$ are unknown ${ }^{74}$. AD GWAS identified gene families including INPP5D, NME4, ABCA2, PLXNB1 were upregulated ${ }^{99}$. Interestingly, transcription factor EB (TFEB) a master regulator for lysosomal biogenesis was overexpressed which is associated with regulated autophagy ${ }^{77}$. Given that the events in AD are non-linear, whether the observed changes are pathogenic or protective is to be determined.

\subsubsection{Cluster4 - Metabolism and Bioenergetics}

Metabolic dysfunction is a well-established characteristic of AD and pathways in cluster4 were enriched for energy metabolism and vesicle mediated transport (Figure 3, Supplemental Table S7, Figure S5). Clinical imaging modalities have consistently shown brain glucose hypometabolism to be an early irregularity in patients with cognitive impairment and in some cases prelude memory deficits ${ }^{1,11}$. Increase in free radical production, a decrease in ATP/ADP ratio and increased rate of oxidant damage to lipids, proteins and mitochondrial DNA characterize the mitochondrial dysfunction in AD 4, 85 . Whether mitochondrial dysfunction is induced by $A \beta$ or an independent upstream process is currently unresolved. Reduction in expression of dynamin 1 like $(D N M 1 L, P E P=1.4 e-$ 03) is consistent with the observation that mitochondrial dynamics shift in favor of fission and is dependent on $A \beta$ overexpression as seen in $A D{ }^{4}$. Increased fission could also be explained by reduced expression of hypoxia inducible domain family member $1 \mathrm{~A}$ $(H I G D 1 A, P E P=1.4 \mathrm{e}-02)$ shown to regulate mitochondrial fusion by inhibiting the cleavage of $O P A 1^{3}$. Interestingly, it has also been attributed to regulate the mitochondrial Y-secretase, a multi-subunit protease complex known to cleave numerous 
transmembrane proteins including notch and APP and whose activity is dysregulated in $A D{ }^{36}$. Presence of amyloid precursor protein $(A P P)$ in the mitochondria is associated with reduced cytochrome c oxidase $(C O X 10, \mathrm{PEP}=3.8 \mathrm{e}-05)$ which is essential for $\mathrm{COX}$ assembly and function of complex IV of the electron transport chain ${ }^{25}$. Although the direct inhibition of $C O X$ on $A \beta$ deposition has shown conflicting results in animal and cell culture models ${ }^{31,79}$, reduced expression of COX may lead to reduced regulatory heme a key metabolite shown to bind with $A \beta^{4}$. Remarkably, HIGD1A also has a role of positively regulating COX complex presenting with a therapeutic treatment strategy applicable across various disorders with dysfunctional OXPHOS activity including AD 37,58 . The expression of malate dehydrogenase $1(\mathrm{MDH} 1, \mathrm{PEP}=7.0 \mathrm{e}-03)$, a key enzyme in the TCA cycle that reversibly catalyzes the oxidation of malate to oxaloacetate was reduced contrary to previous reports of increased protein expression 4,85 . This could reflect variance in methodological approaches, patient demography or preferential transcription for this gene. Decreased MDH1 expression is proposed to enhance oxidative stress and mitochondrial damage due to its interaction with $A K T 1$ activating a cascade of pathway alterations implicated in AD, PD and ALS ${ }^{70}$.

Apart from bioenergetics, alteration in metabolic pathways are observed and associated with risk of developing $A D$. Increased expression of solute carrier family of riboflavin transporters $(S L C 52 A 3, \mathrm{PEP}=3.6 \mathrm{e}-02)$ is intriguing considering riboflavin is a precursor to the complex II substrate flavin adenine dinucleotide. Recent findings of mutations and deficiency of the brain specific transporter SLC52A3 are linked to motor neuron diseases (Brown-Vialetto-Van Laere syndrome, Fazio-Londe Disease) 12, 60, while its overexpression was shown to enhance the proliferatory capability of human glioma 
mediating its effect through suppression of proapoptotic proteins and upregulation of matrix metalloproteinases (MMP) specifically MMP-2 and MMP-9, which have shown to correlate with both CSF $A \beta$ and tau levels from $A D$ patients ${ }^{30,91}$. Understanding the signaling pathways of SLC52A3 warrant further research for validity as clinical diagnostic markers and for dietary considerations ${ }^{45}$. Adiponectin receptor 1 (ADIPOR1, PEP $=8.4 \mathrm{e}-$ 04) that transduce signals from adiponectin, an adipocyte derived hormone involved in control of fat metabolism and insulin sensitivity was upregulated. Due to its relatively recent discovery, data on $A D I P O R 1$ gene expression in $A D$ are lacking though increased plasma and CSF adiponectin has been detected in $\mathrm{MCl}$ and $\mathrm{AD}$ patients ${ }^{84}$.

\subsection{Novel regulatory mechanisms of AD pathogenesis include TGIF1 and EGR3}

We prioritized transcriptional regulators that were significantly enriched in the $A D$ clustered subnetwork and were differentially expressed along with their gene targets in AD when compared to NDC and identified 4 master transcription factors (TF) i.e. SP1, EGR3, TGIF1 and BPTF across all the clusters (Figure 4, Supplemental Table S8, Figure S6). Specificity protein $1(S P 1)$ is dysregulated in $A D$ and can regulate key genes associated with $A D$ pathology i.e., $A P P$, tau and $A P O E{ }^{20}$. Gene members of the early growth response family ( $E G R 3, E G R 1)$ are zinc finger transcription factors essential for synaptic plasticity and memory and are downregulated. Dysregulation of EGR1, a critical microglial homeostatic gene required for maintenance of LTP was associated with pathogenesis of $A P P$ expressing mice while EGR3 critical for short term memory has previously not been associated with $A D 50,65,69$. BPTF/ FAC1 is a chromatin remodeler first identified in $A D$ brain whose overexpression is associated with apoptotic cell death 
81. Transforming growth factor- $\beta$ s $(T G F \beta)$ along with bone morphogenic proteins $(B M P)$ bind via receptors (TGFBR1, TGFBR2, TGFBR3, BMPR2) and activate Smad to regulate gene expression ${ }^{64}$. Transcriptional co-repressor TGIF recruits histone deacetylase (HDAC) to modulate Smad complexes to control the TGF- $\beta$ signaling based activation that have pleiotropic functions and are disrupted in $A D{ }^{89}$.

TGF $\beta$ signaling across multiple cell types can activate several Smad-dependent and independent pathways including MAPKs, NF-KB, PI3K-AKT with contradictory results in a context dependent manner. Consistent with observations in AD brains, overexpression of $T G F \beta$ and its receptors associated with increased $A \beta$ accumulation along with downregulation of BMPR2 point towards dysregulation in signaling mediated by $T G F \beta^{89}$. It is of interest to note that downregulation of BMPR2 observed here could be primarily mediated by downregulation of EGR1, an essential microglial transcription factor ${ }^{65}$. Deficiency in BMPR2 is linked to increased sensitivity to DNA damage along with alterations in DNA repair efficiency and upregulated SP1 could reflect DNA damage control ${ }^{54}$. This could provide an important link between neurodegenerative microglial phenotype and DNA damage observed in AD.

Downregulated nemo like kinase (NLK) along with upregulation of NOTCH4 which is shown to strongly couple to $A D$ risk genes and its downstream co-activator complex RBPJ, point towards ectopic cell cycle reactivation ${ }^{5,13}$. Surprisingly, these observations also coincide with dysregulation of genes involved in reprogramming of cell function i.e. KLF9 is downregulated while SOX2, SALL2 and JUND are upregulated consistent with reduced efficacy of glucocorticoids (GC) in the aging brain ${ }^{47}$. Downregulated KLF9 along 
with upregulated JUND and SALL2 promote cell proliferation and activate PI3K/AKT pathways involved in growth factors while increased expression of SOX2, SOX12 can act synergistically with octamer-binding proteins (POU3F2, POU3F3) to implement a feedforward circuit to increase expression of genes (YES1, ID4) associated with cell reprogramming. Increased expression of $S G K 1$, regulated by BPTF could stem from TGF $\beta$ activated PI3K signaling leading to enhanced activity of NF-KB providing a positive feedback by cross talk between the two pathways 47,64 .

\subsubsection{TGIF1 is neuroprotective in $A D$}

Here we propose increased TGIF1 plays a neuroprotective role by directly repressing or by activating co-repressors to regulate gene expression aimed at arresting cell cycle, enhancing DNA repair and restoring homeostasis (Figure 5). Reduced expression of glycogen synthase kinase 3 B (GSK3B) results in prolonged activation of Smad by inhibition of proteasome-mediated degradation. Increased expression of DNA-binding transcriptional repressor ZEB2 targets activated Smads, which are hub proteins for pathway regulation and control expression for diverse set of genes ${ }^{64}$. WWC1 and its protein product KIBRA which are associated with $A D$, are essential for hippo signaling and synaptic plasticity, with increased expression resulting in inhibition of proliferation ${ }^{48}$. Upregulation of negative regulator of $M Y C$ max interactor $1(M X I 1)$ and transcription regulator myc associated factor $\mathrm{x}(M A X)$ point towards inhibition of $M Y C$ which drives cell cycle re-entry and is increased in AD brains ${ }^{10}$. Tensin 2 (TNS2) is a focal adhesion protein that regulates signaling pathways for cell shape and motility by bridging cytoskeleton and intracellular projections of transmembrane receptors. By acting as a protein tyrosine 
phosphatase, TNS2 dephosphorylates IRS1 reducing its activation for binding to signaling molecules and reduces Akt signaling via a negative feedback loop ${ }^{39}$. Centrosomal protein 57 (CEP57) mediates the mitogenic activity of fibroblast growth factor 2 (FGF2) which shows enhanced binding to senile plaques and neurofibrillary tangles and stimulates downstream signaling pathways (MAPK/ERK, PLC, Akt) 22, 47, 75. Together with the upregulation of fibroblast growth factor receptor 2 (FGFR2), FGF2 possibly potentiates glial mediated neuroinflammation in AD and TGIF1 acts on CEP57 to lead to a net suppression effect on signaling mediated by FGF2 ${ }^{52}$. Eyes absent proteins (EYA2) are transcriptional cofactors with an intrinsic phosphatase activity which phosphorylates histone $\mathrm{H} 2 \mathrm{AX}$ to mediate DNA repair from double strand breaks ${ }^{51}$. Interestingly, upregulation of DDIT4, an inhibitor of mTOR activity which was found to be hyperactivated in $A D$ and mild cognitive impairment but not in pathological aged brains is consistent with role of TGIF1 as neuroprotective ${ }^{86}$.

Upregulation of grb-associated binding protein 2 (GAB2), a consistently replicated GWAS identified $A D$ gene is considered to be neuroprotective and correlates with decreased neurofibrillary tangles and senile plaques ${ }^{101}$. Some of the TGIF1 regulated genes have implication for synaptic transmission. Increased expression of INPPL1 together with decreased SYNJ1 and increased AKT1 could be interpreted as compensatory mechanism to restore the imbalance in the phosphoinositide pool which is crucial for synaptic function and to regulate PI3K/Akt signaling ${ }^{8}$. Similarly, increased expression of syntaxin 4 (STX4) critical for vesicle docking, Wnt frizzled receptor (FZD9) along with coreceptor (LRP5) which regulate synaptic vesicle cycle may be rescue aimed to compensate for effects mediated by EGR3 (see below) ${ }^{42}$. 
TGIF1 also cooperates with the other transcription regulators to mediate the neuroprotective effect (Supplemental Figure S7). Upregulation of CDKN2C regulated by TGIF1 and EGR3 is perhaps a compensatory effect to inhibit the cell cycle progression in absence of direct regulation by $T G F{ }^{64}$. BPTF and TGIF1 regulated zinc-finger myndtype containing $8(Z M Y N D 8)$ is a chromatin reader that recruits the repressive nucleosome remodeling and histone deacetylase (NuRD) complex to transcriptionally silence gene expression as part of the DNA damage response. In conjunction with increased expression of BRD3, paralog of BRD2, ZMYND8 in AD may work to shield H4Ac during double strand repairs as part of the chromatin response to DNA damage ${ }^{35}$.

\subsubsection{EGR3 affects synaptic vesicle processing in $A D$}

Consistent with the association of synaptic loss to $A D$, we observe a concerted downregulation of many genes that code for proteins involved in synaptic vesicle cycle of which key genes are regulated by EGR3 (Figure 6). Vacuolar ATPase (V-ATPase) is an essential proton pump highly expressed on the membrane of the presynaptic vesicle, facilitates neurotransmitter concentration in synaptic vesicles and are differentially expressed in brains of different APOE isoforms ${ }^{96}$. C1 subunit of V-ATPase (ATP6V1C1) is crucial to connect the ATP catalytic domain $\left(\mathrm{V}_{1}\right)$ to the proton-translocation domain $\left(\mathrm{V}_{0}\right)$ and its downregulation has implications on vesicle acidification as well as on membrane fusion. Reduction in expression of neuronal SNARE synaptosome associated protein 25 (SNAP25) along with synaptotagmins (SYT5, SYT13) and syntaxin-binding proteins (STXBP1, STXBP5L) indicate reduced vesicle docking and SNARE-mediated fusion ${ }^{7}$. Furthermore, decrease in vesicle-fusion ATPase (NSF) necessary for disassociating 
SNARE complex from the plasma membrane implicates decreased availability of uncomplexed-SNARE ${ }^{43}$. Reduced clathrin (CLTC) along with adaptor protein complex $(A P 2 A)$, synaptophysin $(S Y P)$ and rab $(R A B 3 A)$ imply reduced vesicle recycling ${ }^{7}$. Targeting the regulation of the dysfunction of clathrin-mediated endocytosis for synaptic receptor holds promise for early intervention strategy ${ }^{78}$. Neurosecretory polypeptide precursor VGF is enhanced in neuronal activity associated with LTP and can be postulated to have a role in sorting of other regulated secretory proteins including glutamate in immature vesicles ${ }^{38}$. Sortilin-related receptor (SORCS3), a neuronal receptor for proteolytic processing of $A P P$ is implicated in $A D$ and is shown to modulate LTD ${ }^{14}$. EGR3 mediated reductions in VGF and SORCS3 aid in the observed phenotype of $A \beta$ induced impairment in LTP and neuronal networks ${ }^{78}$.

2.4 Protein expression of TGIF1 and EGR3 is in concordance with transcript level expression

To substantiate the differences in transcription between $A D$ and non-demented aged brains, we assessed the protein expression of TGIF1 and EGR1, the direct target for $E G R 3$ in pre-frontal cortex of $A D$ and age-matched control brains from an independent cohort. In line with changes in the transcriptome data, we observe an overall $60 \%$ decrease in EGR1 and an $81 \%$ increase in TGIF1 levels in AD brains relative to nondemented control and these trends reach statistical significance. (Figure 7). We found the EGR1 distribution across all cell types in the control brains and the protein levels were particularly diminished in pyramidal neurons in $A D$ brains. On the other hand, upregulation of the nuclear localization of TGIF1 was a frequent feature of glial cells in 
$A D$ brains. Taken together, these results demonstrate the downregulation of EGR3 and is consistent with the role of TGIF1 as a transcription factor.

\section{Conclusions}

By integrating brain tissue specific protein interactions with gene expression profiles derived from large sampling of postmortem transcriptome data, we identified changes in molecular network associated with clinical and pathological Alzheimer's disease (AD) when compared to age matched non-demented controls. Although the mechanisms for neuronal dysfunction in $A D$ are not completely understood yet, the distinct biological clusters identified using Louvain community detection algorithm point towards associations critical for $\operatorname{AD}^{9,23,46,68,85,99}$. Interestingly, the average global expression for clusters corresponding to synaptic transmission, metabolism, cell cycle and survival as well as immune response were downregulated while the upregulated cluster 3 had a large set of uncharacterized pathways and processes. By refining the subject selection, we identified new genes with target potential, confirmed some previous correlations and find lack of associations for other previously reported GWAS computed AD susceptible genes. Based on gene interactions, we propose neuroprotective role for transcriptional repressor TGIF1 which activates other co-repressors to module the TGF $\beta$ signaling and acts to arrest cell cycle re-entry. We find downregulation of EGR3 to be associated to dysregulated synaptic vesicle cycle and postulate to mediate synaptic deficits as seen in AD.

\section{Methods}

4.1 Study Subjects 
The Religious Orders Study and Rush Memory and Aging Project (ROSMAP) are an ongoing longitudinal clinical-pathologic cohort studies of aging and dementia with enrollment of aged individuals without known dementia at baseline ${ }^{6}$. All participants are organ donors. Participants undergo detailed annual clinical evaluation. At death, a postmortem brain evaluation is performed, including silver stain to assay AD pathology (neuritic and diffuse plaques, and neurofibrillary tangles), and $A \beta$ load by image analysis and the density of PHF tau-positive neurofibrillary tangles ${ }^{6}$. The Institutional Review Board of the Rush University Medical Center approved the both studies. An informed consent and an anatomical gift act are obtained from each participant, as is a repository consent that allows for sharing of data and biospecimens.

Subjects were classified as either non demented controls (NDC) or AD based on a weighted combination of complementary information including cognitive score (MMSE) within two years of death along with three separate pathological scores i.e., total amyloid load, neurofibrillary tangles (Braak stage), and presence of neuritic plaques (CERAD score) ${ }^{41}$. Non-demented controls (NDC) included cognitively intact subjects (no diagnosis of mild cognitive impairment within two years of death) containing diffuse amyloid deposits in absence of neuritic plaques, and neurofibrillary tangles confined to the entorhinal region of the brain. For subjects with cognitive impairment, AD diagnosis was assigned based on the high or intermediate likelihood of AD neuropathology as presented in the revised NIA-AA guidelines for neuropathologic assessment of disorders of the brain common in the elderly ${ }^{41}$. A total of 414 subjects who passed these criteria were included in the current study (Table 1). Assessment of the pathological metrics as well as the characteristics of the cohort has been previously described in detail 6, 95 . 


\section{Table 1: Sample demographics of the subjects included in the study}

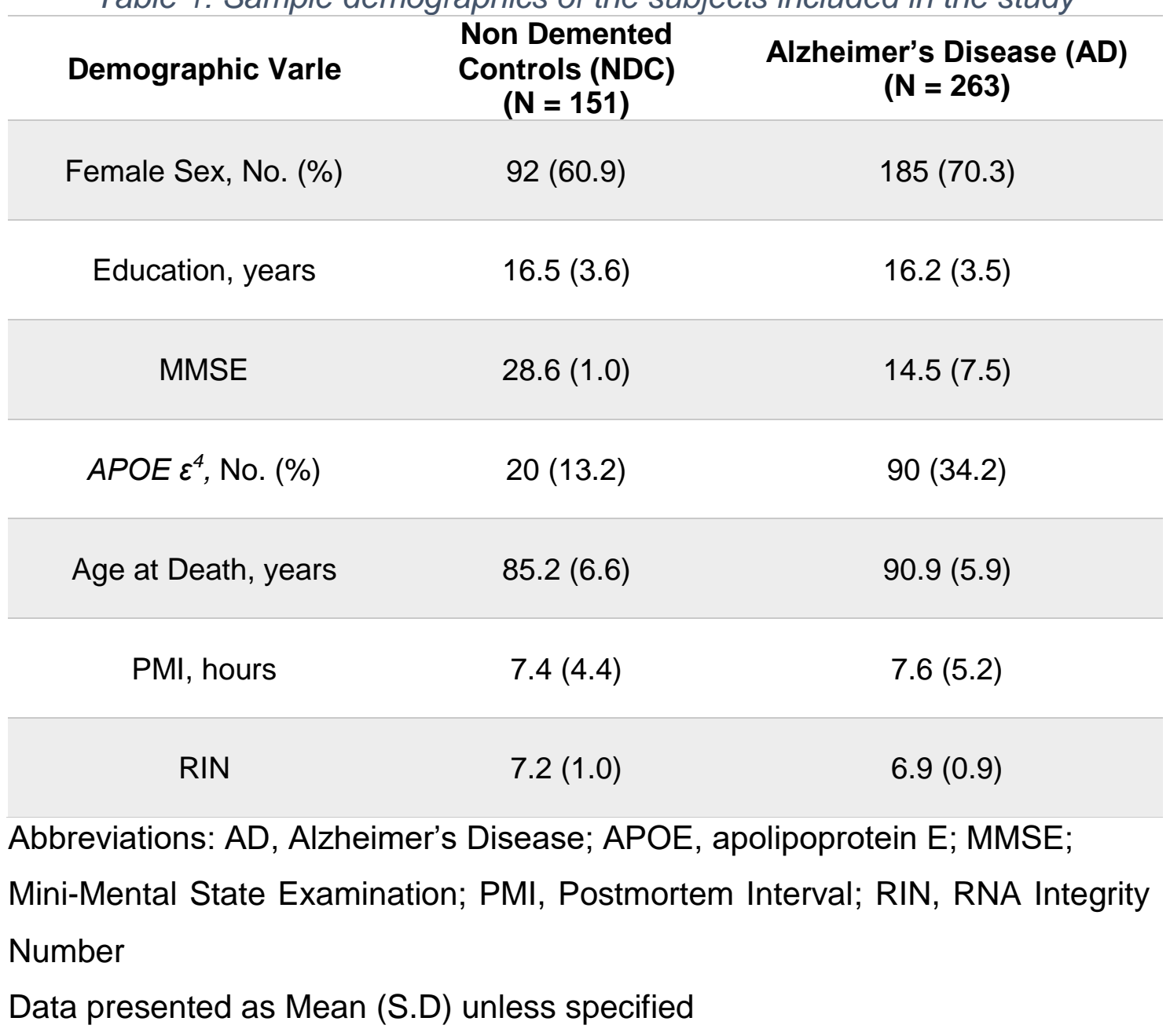

\subsection{Gene Expression Analysis}

RNA-seq data (101 bp paired end reads with coverage of 50 million) was obtained from RNA extracted from the gray matter of the dorsolateral prefrontal cortex. Expression in the form of fragments per kilobase of exon per million reads mapped (FPKM) was estimated by RSEM. Details of the RNA-seq data pipeline can be found in previous literature 68, 95 .

Expression data were downloaded from ROSMAP as FPKM values and normalized using a multi-loess method and batch effects removed using COMBAT algorithm ${ }^{44}$. For the log- 
transformed expression data, linear regression models were fit to account for effects of diagnostic conditions as well as confounding covariates of age at death, sex, postmortem interval (PMI) and APOE status for the risk allele. Test for statistical significance was achieved by implementation of a Bayesian strategy of Lönnstedt and Speed as implemented in $R$ package limma ${ }^{72}$. Genes are sorted by their posterior error probability (PEP) and considered significant at PEP $<0.05$.

\subsection{Background Interactome}

The background interactome on which the network analysis was conducted was built from the brain-specific network in the GIANT database ${ }^{34}$. This network is composed of edges which support a strong tissue-specific functional interaction between source and target genes. This network, thresholded at an edge confidence of 0.2 , contains 14,545 genes, and 1,370,174 edges, and represents genes and interactions which are likely to be present in normal brain function. The identified differentially expressed genes were mapped onto this network to create an AD subnetwork. Network visualization was accomplished using visJS2Jupyter ${ }^{73}$.

\subsection{Clustering analysis}

Clusters were identified in the $A D$ subnetwork using a network-based modularity maximization algorithm ${ }^{88}$. This algorithm, commonly referred to as the Louvain clustering algorithm, identifies groups of nodes which have many connections within groups, and few connections between groups, and is efficient at extracting community structure from large networks. The algorithm iteratively maximizes the modularity, $\mathrm{Q}$, defined as follows: 


$$
Q=\frac{1}{2 m} \sum_{i, j}\left[A_{i j}-\frac{k_{i} k_{j}}{2 m}\right] \delta\left(c_{i}, c_{j}\right)
$$

Where $A_{i j}$ is the binary adjacency matrix element representing the presence or absence of the connection between node $i$ and node $j, k_{i}$ represents the degree of node $i$, where degree is defined as the number of nodes directly connected to node $i, c_{i}$ is the community to which node $i$ belongs, and the function $\delta(x, y)$ is 1 if $x=y$, and otherwise it is $0 . \quad m$ is the total number of edges in the network, $m=\frac{1}{2} \sum_{i j} A_{i j}$ (divided by two to avoid double counting). See Blondel et al ${ }^{88}$ for more details on the algorithm.

The Louvain algorithm does not require selection or fine-tuning of parameters, as do some other clustering algorithms such as, K-means clustering and hierarchical clustering (such as are used in the WGCNA R package). Rather, clusters are determined by finding groupings of genes which have many within group connections, and few between group connections. This algorithm has proven useful in detecting modules, or clusters, in protein-protein interaction networks, such as the one used here ${ }^{29,87}$.

\subsection{Functional Annotation and Pathway Analysis}

To identify the underlying biological functions enriched in $A D$, Gene Set Enrichment Analysis (GSEA) was implemented which identifies the enrichment of functionally defined gene sets using a modified Kolmogorov-Smirnov statistic ${ }^{82}$. The Molecular Signature Database (MSigDb v6.0) ${ }^{82}$ consists of well over 4000 gene sets from functionally wellestablished or published pathways from databases including Gene Ontology (GO), the Kyoto Encyclopedia of Gene and Genomes (KEGG), BioCarta, and Reactome. Statistical 
significance after adjusting for multiple testing is defined at FDR $<0.05$. Gene set-based permutation test of 1000 permutations was applied. Detailed description of the GSEA algorithm, testing metrics and the implementation have been described previously 82 . Hypergeometric test was utilized to test of statistical significance of the enriched biological process and pathways identified for the differential expressed genes in the clusters ${ }^{90,97}$. Overrepresentation enrichment analysis was conducted using the full set of genes from the $A D$ subnetwork as the reference gene set, corrected for multiple testing using the Benjamini-Hochberg procedure and FDR $<0.05$ was considered significant.

\subsection{Transcriptional Regulation Analysis}

To identify transcription factors (TF) likely related to $A D$, we analyzed for enrichment of transcription factor targets in the $A D$ clustered subnetwork ${ }^{90}$. This resulted in 16 significantly enriched transcription factors (Supplementary Table S8). We further filtered this list by differential expression in AD vs NDC, resulting in 4 candidate TFs. These four TFs are all significantly differentially expressed in AD as compared to NDC and have more targets than would be expected by chance in the AD subnetwork (Supplemental Figure S7). The TF subnetwork is visualized to highlight the connections between TF and targets along with connections between targets using visJS2Jupyter ${ }^{73}$.

\subsection{Validation of TGIF1 and EGR3}

We assessed the protein expression and distribution of TGIF1 and EGR3 target EGR1 in prefrontal cortex brain tissue of clinically diagnosed pathologically confirmed $A D$ and from age matched controls using standard immunohistochemistry techniques. The subjects 
were selected based on diagnostic criteria as described above and brain tissue samples were obtained from University of California, San Diego Alzheimer's Disease Research Center (ADRC) brain bank. Tissue samples were obtained from two non-demented aged controls ( $81.5 \pm 2.1$ years, $12 \pm 3$ hours, $50 \%$ F) and three AD subjects ( $83 \pm 4.3$ years, $6.6 \pm 1.1$ hours, $67 \%$ F). Paraffin-embedded tissue blocks were serially sectioned and incubated with either TGIF antibody ( $\mathrm{H}-1)$ (Santa Cruz Biotechnology, Dallas, TX) or EGR1 antibody (Cell Signaling Technology, Danvers, MA). Staining was performed with chromogen $3,3^{\prime}$-diaminobenzidine (DAB) to identify the immunoreactive structures and counterstained with hematoxylin. All images were acquired using an upright microscope (Leica DM5500B) at a resolution of $1392 \times 1040$ pixels and consistent aperture and gain settings. Custom designed macro was used to convert the optical images to grayscale, threshold and measure the TGIF or EGR1 positive area fraction relative to the optical field. Due to the non-normal distribution of the data, test of significance was evaluated using Wilcoxon-Mann-Whitney test and differences were considered significant when $\mathrm{p}<$ 0.05 .

Acknowledgements

We gratefully acknowledge the study participants. This study was funding by the VA San Diego, Grant BX003040. The contents do not represent the views of the U.S Department of veterans Affairs or the United States Government. The project described was partially supported by the National Institutes of Health, Grant UL1TR001442 of CTSA, and P30AG10161, RF1AG15819, R01AG17917, U01AG46'52. The content is solely the responsibility of the authors and does not necessarily represent the official views of the $\mathrm{NIH}$. 


\section{References}

1. Adlard P. A., B. A. Tran, D. I. Finkelstein, P. M. Desmond, L. A. Johnston, A. I. Bush and G. F. Egan. A review of $\beta$-amyloid neuroimaging in Alzheimer's disease. Frontiers in Neuroscience 8: 327, 2014.

2. $\quad$ Alazami Anas M., N. Patel, Hanan E. Shamseldin, S. Anazi, Mohammed S. Al-Dosari, F. Alzahrani, H. Hijazi, M. Alshammari, Mohammed A. Aldahmesh, Mustafa A. Salih, E. Faqeih, A. Alhashem, Fahad A. Bashiri, M. Al-Owain, Amal Y. Kentab, S. Sogaty, S. Al Tala, M.-H. Temsah, M. Tulbah, Rasha F. Aljelaify, Saad A. Alshahwan, Mohammed Z. Seidahmed, Adnan A. Alhadid, H. Aldhalaan, F. AlQallaf, W. Kurdi, M. Alfadhel, Z. Babay, M. Alsogheer, N. Kaya, Zuhair N. Al-Hassnan, Ghada M. H. Abdel-Salam, N. Al-Sannaa, F. Al Mutairi, Heba Y. El Khashab, S. Bohlega, X. Jia, Henry C. Nguyen, R. Hammami, N. Adly, Jawahir Y. Mohamed, F. Abdulwahab, N. Ibrahim, Ewa A. Naim, B. Al-Younes, Brian F. Meyer, M. Hashem, R. Shaheen, Y. Xiong, M. Abouelhoda, Abdulrahman A. Aldeeri, Dorota M. Monies and Fowzan S. Alkuraya. Accelerating Novel Candidate Gene Discovery in Neurogenetic Disorders via WholeExome Sequencing of Prescreened Multiplex Consanguineous Families. Cell Reports 10: 148-161, 2015.

3. An H.-J., G. Cho, J.-O. Lee, S.-G. Paik, Y. S. Kim and H. Lee. Higd-1 a interacts with Opa1 and is required for the morphological and functional integrity of mitochondria. Proceedings of the National Academy of Sciences 110: 13014-13019, 2013.

4. Atamna H. and W. H. Frey. Mechanisms of mitochondrial dysfunction and energy deficiency in Alzheimer's disease. Mitochondrion 7: 297-310, 2007.

5. Bennet A. M., C. A. Reynolds, U. K. Eriksson, M.-g. Hong, K. Blennow, M. Gatz, A. Alexeyenko, N. L. Pedersen and J. A. Prince. Genetic Association of sequence variants near AGER/NOTCH4 and Dementia. Journal of Alzheimer's disease : JAD 24: 475-484, 2011.

6. Bennett D. A., J. A. Schneider, Z. Arvanitakis and R. S. Wilson. OVERVIEW AND FINDINGS FROM THE RELIGIOUS ORDERS STUDY. Current Alzheimer Research 9: 628645, 2012.

7. Bereczki E., P. T. Francis, D. Howlett, J. B. Pereira, K. Höglund, A. Bogstedt, A. CedazoMinguez, J.-H. Baek, T. Hortobágyi, J. Attems, C. Ballard and D. Aarsland. Synaptic proteins predict cognitive decline in Alzheimer's disease and Lewy body dementia. Alzheimer's \& Dementia 12: 1149-1158, 2016.

8. Berman D. E., C. Dall'Armi, S. V. Voronov, L. B. J. McIntire, H. Zhang, A. Z. Moore, A. Staniszewski, O. Arancio, T.-W. Kim and G. Di Paolo. Oligomeric amyloid- $\beta$ peptide disrupts phosphatidylinositol-4,5-bisphosphate metabolism. Nature Neuroscience 11: 547-554, 2008.

9. Blalock E. M., J. W. Geddes, K. C. Chen, N. M. Porter, W. R. Markesbery and P. W. Landfield. Incipient Alzheimer's disease: Microarray correlation analyses reveal major transcriptional and tumor suppressor responses. Proceedings of the National Academy of Sciences of the United States of America 101: 2173-2178, 2004.

10. Blom E. S., Y. Wang, L. Skoglund, A. C. Hansson, M. Ubaldi, A. Lourdusamy, W. H. Sommer, M. Mielke, B. T. Hyman, M. Heilig, L. Lannfelt, L. N. G. Nilsson and M. Ingelsson. Increased mRNA Levels of TCF7L2 and MYC of the Wnt Pathway in Tg-ArcSwe Mice and Alzheimer's Disease Brain. International Journal of Alzheimer's Disease 2011: 936580, 2011. 
11. Bloudek L. M., D. E. Spackman, M. Blankenburg and S. D. Sullivan. Review and metaanalysis of biomarkers and diagnostic imaging in Alzheimer's disease. J Alzheimers Dis 26: 627645, 2011.

12. Bosch A. M., N. G. G. M. Abeling, L. Ijlst, H. Knoester, W. L. van der Pol, A. E. M. Stroomer, R. J. Wanders, G. Visser, F. A. Wijburg, M. Duran and H. R. Waterham. BrownVialetto-Van Laere and Fazio Londe syndrome is associated with a riboflavin transporter defect mimicking mild MADD: a new inborn error of metabolism with potential treatment. Journal of Inherited Metabolic Disease 34: 159-164, 2011.

13. Brai E., N. Alina Raio and L. Alberi. Notch1 hallmarks fibrillary depositions in sporadic Alzheimer's disease. Acta Neuropathologica Communications 4: 64, 2016.

14. Breiderhoff T., G. B. Christiansen, L. T. Pallesen, C. Vaegter, A. Nykjaer, M. M. Holm, S. Glerup and T. E. Willnow. Sortilin-Related Receptor SORCS3 Is a Postsynaptic Modulator of Synaptic Depression and Fear Extinction. Plos One 8: e75006, 2013.

15. Brien G. L., G. Gambero, D. J. O'Connell, E. Jerman, S. A. Turner, C. M. Egan, E. J. Dunne, M. C. Jurgens, K. Wynne, L. Piao, A. J. Lohan, N. Ferguson, X. Shi, K. M. Sinha, B. J. Loftus, G. Cagney and A. P. Bracken. Polycomb PHF19 binds H3K36me3 and recruits PRC2 and demethylase NO66 to embryonic stem cell genes during differentiation. Nature Structural \& Molecular Biology 19: 1273-1281, 2012.

16. Calvo S. E., K. R. Clauser and V. K. Mootha. MitoCarta2.0: an updated inventory of mammalian mitochondrial proteins. Nucleic Acids Research 44: D1251-D1257, 2016.

17. Cardinale A., M. Racaniello, S. Saladini, G. De Chiara, C. Mollinari, M. C. de Stefano, M. Pocchiari, E. Garaci and D. Merlo. Sublethal Doses of $\beta$-Amyloid Peptide Abrogate DNAdependent Protein Kinase Activity. The Journal of Biological Chemistry 287: 2618-2631, 2012.

18. Chaban Y., E. J. Boekema and N. V. Dudkina. Structures of mitochondrial oxidative phosphorylation supercomplexes and mechanisms for their stabilisation. Biochimica et Biophysica Acta (BBA) - Bioenergetics 1837: 418-426, 2014.

19. Cheloufi S., U. Elling, B. Hopfgartner, Y. L. Jung, J. Murn, M. Ninova, M. Hubmann, A. I. Badeaux, C. E. Ang, D. Tenen, D. J. Wesche, N. Abazova, M. Hogue, N. Tasdemir, J. Brumbaugh, P. Rathert, J. Jude, F. Ferrari, A. Blanco, M. Fellner, D. Wenzel, M. Zinner, S. E. Vidal, O. Bell, M. Stadtfeld, H. Y. Chang, G. Almouzni, S. W. Lowe, J. Rinn, M. Wernig, A. Aravin, Y. Shi, P. Park, J. M. Penninger, J. Zuber and K. Hochedlinger. The histone chaperone CAF-1 safeguards somatic cell identity. Nature 528: 218-224, 2015.

20. Citron B. A., J. S. Dennis, R. S. Zeitlin and V. Echeverria. Transcription factor Sp1 dysregulation in Alzheimer's disease. Journal of Neuroscience Research 86: 2499-2504, 2008.

21. Cocco C., F. D’Amato, B. Noli, A. Ledda, C. Brancia, P. Bongioanni and G.-L. Ferri. Distribution of VGF peptides in the human cortex and their selective changes in Parkinson's and Alzheimer's diseases. Journal of Anatomy 217: 683-693, 2010.

22. Cuevas R., N. Korzeniewski, Y. Tolstov, M. Hohenfellner and S. Duensing. FGF-2 Disrupts Mitotic Stability in Prostate Cancer through the Intracellular Trafficking Protein CEP57. Cancer Research 73: 1400-1410, 2013.

23. Davydov V., L. A. Hansen and D. A. Shackelford. Is DNA repair compromised in Alzheimer's disease? Neurobiology of Aging 24: 953-968, 2003.

24. De Blasio D., S. Fumagalli, L. Longhi, F. Orsini, A. Palmioli, M. Stravalaci, G. Vegliante, E. R. Zanier, A. Bernardi, M. Gobbi and M.-G. De Simoni. Pharmacological inhibition of mannose-binding lectin ameliorates neurobehavioral dysfunction following experimental traumatic brain injury. Journal of Cerebral Blood Flow \& Metabolism 37: 938-950, 2016. 
25. Devi L., B. M. Prabhu, D. F. Galati, N. G. Avadhani and H. K. Anandatheerthavarada. Accumulation of Amyloid Precursor Protein in the Mitochondrial Import Channels of Human Alzheimer's Disease Brain Is Associated with Mitochondrial Dysfunction. The Journal of Neuroscience 26: 9057-9068, 2006.

26. El-Khamisy S. F., G. M. Saifi, M. Weinfeld, F. Johansson, T. Helleday, J. R. Lupski and K. W. Caldecott. Defective DNA single-strand break repair in spinocerebellar ataxia with axonal neuropathy-1. Nature 434: 108-113, 2005.

27. Escott-Price V., C. Bellenguez, L.-S. Wang, S.-H. Choi, D. Harold, L. Jones, P. Holmans, A. Gerrish, A. Vedernikov, A. Richards, A. L. DeStefano, J.-C. Lambert, C. A. Ibrahim-Verbaas, A. C. Naj, R. Sims, G. Jun, J. C. Bis, G. W. Beecham, B. Grenier-Boley, G. Russo, T. A. ThorntonWells, N. Denning, A. V. Smith, V. Chouraki, C. Thomas, M. A. Ikram, D. Zelenika, B. N. Vardarajan, Y. Kamatani, C.-F. Lin, H. Schmidt, B. Kunkle, M. L. Dunstan, M. Vronskaya, C. the United Kingdom Brain Expression, A. D. Johnson, A. Ruiz, M.-T. Bihoreau, C. Reitz, F. Pasquier, P. Hollingworth, O. Hanon, A. L. Fitzpatrick, J. D. Buxbaum, D. Campion, P. K. Crane, C. Baldwin, T. Becker, V. Gudnason, C. Cruchaga, D. Craig, N. Amin, C. Berr, O. L. Lopez, P. L. De Jager, V. Deramecourt, J. A. Johnston, D. Evans, S. Lovestone, L. Letenneur, I. Hernández, D. C. Rubinsztein, G. Eiriksdottir, K. Sleegers, A. M. Goate, N. Fiévet, M. J. Huentelman, M. Gill, K. Brown, M. I. Kamboh, L. Keller, P. Barberger-Gateau, B. McGuinness, E. B. Larson, A. J. Myers, C. Dufouil, S. Todd, D. Wallon, S. Love, E. Rogaeva, J. Gallacher, P. S. George-Hyslop, J. Clarimon, A. Lleo, A. Bayer, D. W. Tsuang, L. Yu, M. Tsolaki, P. Bossù, G. Spalletta, P. Proitsi, J. Collinge, S. Sorbi, F. S. Garcia, N. C. Fox, J. Hardy, M. C. D. Naranjo, P. Bosco, R. Clarke, C. Brayne, D. Galimberti, E. Scarpini, U. Bonuccelli, M. Mancuso, G. Siciliano, S. Moebus, P. Mecocci, M. D. Zompo, W. Maier, H. Hampel, A. Pilotto, A. Frank-García, F. Panza, V. Solfrizzi, P. Caffarra, B. Nacmias, W. Perry, M. Mayhaus, L. Lannfelt, H. Hakonarson, S. Pichler, M. M. Carrasquillo, M. Ingelsson, D. Beekly, V. Alvarez, F. Zou, O. Valladares, S. G. Younkin, E. Coto, K. L. Hamilton-Nelson, W. Gu, C. Razquin, P. Pastor, I. Mateo, M. J. Owen, K. M. Faber, P. V. Jonsson, O. Combarros, M. C. O'Donovan, L. B. Cantwell, H. Soininen, D. Blacker, S. Mead, T. H. Mosley, Jr., D. A. Bennett, T. B. Harris, L. Fratiglioni, C. Holmes, R. F. A. G. de Bruijn, P. Passmore, T. J. Montine, K. Bettens, J. I. Rotter, A. Brice, K. Morgan, T. M. Foroud, W. A. Kukull, D. Hannequin, J. F. Powell, M. A. Nalls, K. Ritchie, K. L. Lunetta, J. S. K. Kauwe, E. Boerwinkle, M. Riemenschneider, M. Boada, M. Hiltunen, E. R. Martin, R. Schmidt, D. Rujescu, J.-F. Dartigues, R. Mayeux, C. Tzourio, A. Hofman, M. M. Nöthen, C. Graff, B. M. Psaty, J. L. Haines, M. Lathrop, M. A. Pericak-Vance, L. J. Launer, C. Van Broeckhoven, L. A. Farrer, C. M. van Duijn, A. Ramirez, S. Seshadri, G. D. Schellenberg, P. Amouyel and J. Williams. Gene-Wide Analysis Detects Two New Susceptibility Genes for Alzheimer's Disease. Plos One 9: e94661, 2014.

28. Feng T., Y. Liu, C. Li, Z. Li and H. Cai. DEK proto-oncogene is highly expressed in astrocytic tumors and regulates glioblastoma cell proliferation and apoptosis. Tumor Biology 39: $1010428317716248,2017$.

29. Fortunato S. Community detection in graphs. Physics Reports 486: 75-174, 2010.

30. Fu T., Y. Liu, Q. Wang, Z. Sun, H. Di, W. Fan, M. Liu and J. Wang. Overexpression of riboflavin transporter 2 contributes toward progression and invasion of glioma. Neuroreport 27: 1167-1173, 2016.

31. Fukui H., F. Diaz, S. Garcia and C. T. Moraes. Cytochrome c oxidase deficiency in neurons decreases both oxidative stress and amyloid formation in a mouse model of Alzheimer's disease. Proceedings of the National Academy of Sciences 104: 14163-14168, 2007. 
32. Fuller J. P., J. B. Stavenhagen and J. L. Teeling. New roles for Fc receptors in neurodegeneration-the impact on Immunotherapy for Alzheimer's Disease. Frontiers in Neuroscience 8: 235, 2014.

33. Gensel J. C., Y. Wang, Z. Guan, K. A. Beckwith, K. J. Braun, P. Wei, D. M. McTigue and P. G. Popovich. Toll-Like Receptors and Dectin-1, a C-Type Lectin Receptor, Trigger Divergent Functions in CNS Macrophages. The Journal of Neuroscience 35: 9966-9976, 2015.

34. Greene C. S., A. Krishnan, A. K. Wong, E. Ricciotti, R. A. Zelaya, D. S. Himmelstein, R. Zhang, B. M. Hartmann, E. Zaslavsky, S. C. Sealfon, D. I. Chasman, G. A. FitzGerald, K. Dolinski, T. Grosser and O. G. Troyanskaya. Understanding multicellular function and disease with human tissue-specific networks. 47: 569, 2015.

35. Gursoy-Yuzugullu O., C. Carman and B. D. Price. Spatially restricted loading of BRD2 at DNA double-strand breaks protects $\mathrm{H} 4$ acetylation domains and promotes DNA repair. Scientific Reports 7: 12921, 2017.

36. Hayashi H., H. Nakagami, M. Takeichi, M. Shimamura, N. Koibuchi, E. Oiki, N. Sato, H. Koriyama, M. Mori, R. Gerardo Araujo, A. Maeda, R. Morishita, K. Tamai and Y. Kaneda. HIG1, a novel regulator of mitochondrial $\gamma$-secretase, maintains normal mitochondrial function. The FASEB Journal 26: 2306-2317, 2012.

37. Hayashi T., Y. Asano, Y. Shintani, H. Aoyama, H. Kioka, O. Tsukamoto, M. Hikita, K. Shinzawa-Itoh, K. Takafuji, S. Higo, H. Kato, S. Yamazaki, K. Matsuoka, A. Nakano, H. Asanuma, M. Asakura, T. Minamino, Y.-i. Goto, T. Ogura, M. Kitakaze, I. Komuro, Y. Sakata, T. Tsukihara, S. Yoshikawa and S. Takashima. Higdla is a positive regulator of cytochrome c oxidase. Proceedings of the National Academy of Sciences 112: 1553-1558, 2015.

38. Hendrickson R. C., A. Y. H. Lee, Q. Song, A. Liaw, M. Wiener, C. P. Paweletz, J. L. Seeburger, J. Li, F. Meng, E. G. Deyanova, M. T. Mazur, R. E. Settlage, X. Zhao, K. Southwick, Y. Du, D. Holder, J. R. Sachs, O. F. Laterza, A. Dallob, D. L. Chappell, K. Snyder, V. Modur, E. King, C. Joachim, A. Y. Bondarenko, M. Shearman, K. A. Soper, A. D. Smith, W. Z. Potter, K. S. Koblan, A. B. Sachs and N. A. Yates. High Resolution Discovery Proteomics Reveals Candidate Disease Progression Markers of Alzheimer's Disease in Human Cerebrospinal Fluid. Plos One 10: e0135365, 2015.

39. Hong S.-Y., Y.-P. Shih, P. Sun, W.-J. Hsieh, W.-C. Lin and S. H. Lo. Down-regulation of tensin2 enhances tumorigenicity and is associated with a variety of cancers. Oncotarget 7: 3814338153, 2016.

40. Hooff G. P., W. G. Wood, W. E. Müller and G. P. Eckert. Isoprenoids, Small GTPases and Alzheimer's Disease. Biochimica et biophysica acta 1801: 896-905, 2010.

41. Hyman B. T., C. H. Phelps, T. G. Beach, E. H. Bigio, N. J. Cairns, M. C. Carrillo, D. W. Dickson, C. Duyckaerts, M. P. Frosch, E. Masliah, S. S. Mirra, P. T. Nelson, J. A. Schneider, D. R. Thal, B. Thies, J. Q. Trojanowski, H. V. Vinters and T. J. Montine. National Institute on AgingAlzheimer's Association guidelines for the neuropathologic assessment of Alzheimer's disease. Alzheimer's \& dementia : the journal of the Alzheimer's Association 8: 1-13, 2012.

42. Inestrosa N. C. and L. Varela-Nallar. Wnt signaling in the nervous system and in Alzheimer's disease. Journal of Molecular Cell Biology 6: 64-74, 2014.

43. Jahn R. and R. H. Scheller. SNAREs - engines for membrane fusion. Nature Reviews Molecular Cell Biology 7: 631, 2006.

44. Johnson W. E., C. Li and A. Rabinovic. Adjusting batch effects in microarray expression data using empirical Bayes methods. Biostatistics 8: 118-127, 2007. 
45. Jones J. M., R. Korczak, R. J. Peña and H. J. Braun. CIMMYT Series on Carbohydrates, Wheat, Grains, and Health: Carbohydrates and Vitamins from Grains and Their Relationships to Mild Cognitive Impairment, Alzheimer's Disease, and Parkinson's Disease. Cereal Foods World 62: 65-75, 2017.

46. Jones L., J.-C. Lambert, L.-S. Wang, S.-H. Choi, D. Harold, A. Vedernikov, V. EscottPrice, T. Stone, A. Richards, C. Bellenguez, C. A. Ibrahim-Verbaas, A. C. Naj, R. Sims, A. Gerrish, G. Jun, A. L. DeStefano, J. C. Bis, G. W. Beecham, B. Grenier-Boley, G. Russo, T. A. Thornton-Wells, N. Jones, A. V. Smith, V. Chouraki, C. Thomas, M. A. Ikram, D. Zelenika, B. N. Vardarajan, Y. Kamatani, C.-F. Lin, H. Schmidt, B. Kunkle, M. L. Dunstan, A. Ruiz, M.-T. Bihoreau, C. Reitz, F. Pasquier, P. Hollingworth, O. Hanon, A. L. Fitzpatrick, J. D. Buxbaum, D. Campion, P. K. Crane, T. Becker, V. Gudnason, C. Cruchaga, D. Craig, N. Amin, C. Berr, O. L. Lopez, P. L. De Jager, V. Deramecourt, J. A. Johnston, D. Evans, S. Lovestone, L. Letteneur, J. Kornhuber, L. Tárraga, D. C. Rubinsztein, G. Eiriksdottir, K. Sleegers, A. M. Goate, N. Fiévet, M. J. Huentelman, M. Gill, V. Emilsson, K. Brown, M. I. Kamboh, L. Keller, P. Barberger-Gateau, B. McGuinness, E. B. Larson, A. J. Myers, C. Dufouil, S. Todd, D. Wallon, S. Love, P. Kehoe, E. Rogaeva, J. Gallacher, P. S. George-Hyslop, J. Clarimon, A. Lleỏ, A. Bayer, D. W. Tsuang, L. Yu, M. Tsolaki, P. Bossù, G. Spalletta, P. Proitsi, J. Collinge, S. Sorbi, F. S. Garcia, N. Fox, J. Hardy, M. C. D. Naranjo, C. Razquin, P. Bosco, R. Clarke, C. Brayne, D. Galimberti, M. Mancuso, C. Mrc, S. Moebus, P. Mecocci, M. del Zompo, W. Maier, H. Hampel, A. Pilotto, M. Bullido, F. Panza, P. Caffarra, B. Nacmias, J. R. Gilbert, M. Mayhaus, F. Jessen, M. Dichgans, L. Lannfelt, H. Hakonarson, S. Pichler, M. M. Carrasquillo, M. Ingelsson, D. Beekly, V. Alavarez, F. Zou, O. Valladares, S. G. Younkin, E. Coto, K. L. Hamilton-Nelson, I. Mateo, M. J. Owen, K. M. Faber, P. V. Jonsson, O. Combarros, M. C. O'Donovan, L. B. Cantwell, H. Soininen, D. Blacker, S. Mead, T. H. Mosley, D. A. Bennett, T. B. Harris, L. Fratiglioni, C. Holmes, R. F. A. G. de Bruijn, P. Passmore, T. J. Montine, K. Bettens, J. I. Rotter, A. Brice, K. Morgan, T. M. Foroud, W. A. Kukull, D. Hannequin, J. F. Powell, M. A. Nalls, K. Ritchie, K. L. Lunetta, J. S. K. Kauwe, E. Boerwinkle, M. Riemenschneider, M. Boada, M. Hiltunen, E. R. Martin, P. Pastor, R. Schmidt, D. Rujescu, J.F. Dartigues, R. Mayeux, C. Tzourio, A. Hofman, M. M. Nöthen, C. Graff, B. M. Psaty, J. L. Haines, M. Lathrop, M. A. Pericak-Vance, L. J. Launer, L. A. Farrer, C. M. van Duijn, C. Van Broekhoven, A. Ramirez, G. D. Schellenberg, S. Seshadri, P. Amouyel, J. Williams and P. A. Holmans. Convergent genetic and expression data implicate immunity in Alzheimer's disease. Alzheimer's \& dementia : the journal of the Alzheimer's Association 11: 658-671, 2015.

47. Juszczak G. R. and A. M. Stankiewicz. Glucocorticoids, genes and brain function. Progress in Neuro-Psychopharmacology and Biological Psychiatry 2017.

48. Kawai E., N. Shibata, T. Nagata, S. Shinagawa, K. Tgai, T. Ohnuma, H. Shimazaki, A. Toda, K. Kasanuki, T. Takayama, A. Suzuki, K. Nakayama, H. Yamada and H. Arai. Genetic Association Between KIBRA Polymorphism and Alzheimer's Disease with in a Japanese Population. NeuroMolecular Medicine 17: 170-177, 2015.

49. Koizumi H., H. Fujioka, K. Togashi, J. Thompson, J. R. Yates, J. G. Gleeson and K. Emoto. DCLK1 phosphorylates the microtubule-associated protein MAP7D1 to promote axon elongation in cortical neurons. Developmental Neurobiology 77: 493-510, 2017.

50. Koldamova R., J. Schug, M. Lefterova, A. A. Cronican, N. F. Fitz, F. A. Davenport, A. Carter, E. L. Castranio and I. Lefterov. Genome-wide approaches reveal EGR1-controlled regulatory networks associated with neurodegeneration. Neurobiology of Disease 63: 107-114, 2014. 
51. Krishnan N., D. G. Jeong, S.-K. Jung, S. E. Ryu, A. Xiao, C. D. Allis, S. J. Kim and N. K. Tonks. Dephosphorylation of the C-terminal Tyrosyl Residue of the DNA Damage-related Histone H2A.X Is Mediated by the Protein Phosphatase Eyes Absent. The Journal of Biological Chemistry 284: 16066-16070, 2009.

52. Lee M., Y. Kang, K. Suk, C. Schwab, S. Yu and P. L. McGeer. Acidic Fibroblast Growth Factor (FGF) Potentiates Glial-mediated Neurotoxicity by Activating FGFR2 IIIb Protein. The Journal of Biological Chemistry 286: 41230-41245, 2011.

53. Li G., C. Warden, Z. Zou, J. Neman, J. S. Krueger, A. Jain, R. Jandial and M. Chen. Altered Expression of Polycomb Group Genes in Glioblastoma Multiforme. Plos One 8: e80970, 2013.

54. Li M., S. Vattulainen, J. Aho, M. Orcholski, V. Rojas, K. Yuan, M. Helenius, P. Taimen, S. Myllykangas, V. D. J. Perez, J. W. Koskenvuo and T.-P. Alastalo. Loss of Bone Morphogenetic Protein Receptor 2 Is Associated with Abnormal DNA Repair in Pulmonary Arterial Hypertension. American Journal of Respiratory Cell and Molecular Biology 50: 1118-1128, 2014.

55. Limon A., J. M. Reyes-Ruiz and R. Miledi. Loss of functional GABA(A) receptors in the Alzheimer diseased brain. Proceedings of the National Academy of Sciences of the United States of America 109: 10071-10076, 2012.

56. Lin L., W. Sun, B. Throesch, F. Kung, J. T. Decoster, C. J. Berner, R. E. Cheney, B. Rudy and D. A. Hoffman. DPP6 regulation of dendritic morphogenesis impacts hippocampal synaptic development. Nature communications 4: 2270-2270, 2013.

57. Luchetti S., K. Bossers, S. Van de Bilt, V. Agrapart, R. R. Morales, G. V. Frajese and D. F. Swaab. Neurosteroid biosynthetic pathways changes in prefrontal cortex in Alzheimer's disease. Neurobiology of Aging 32: 1964-1976, 2011.

58. Lunnon K., A. Keohane, R. Pidsley, S. Newhouse, J. Riddoch-Contreras, E. B. Thubron, M. Devall, H. Soininen, I. Kłoszewska, P. Mecocci, M. Tsolaki, B. Vellas, L. Schalkwyk, R. Dobson, A. N. Malik, J. Powell, S. Lovestone and A. Hodges. Mitochondrial genes are altered in blood early in Alzheimer's disease. Neurobiology of Aging 53: 36-47, 2017.

59. Mandal M., K. M. Hamel, M. Maienschein-Cline, A. Tanaka, G. Teng, J. H. Tuteja, J. J. Bunker, N. Bahroos, J. J. Eppig, D. G. Schatz and M. R. Clark. Histone Reader BRWD1 Targets and Restricts Recombination to the Igk Locus. Nature immunology 16: 1094-1103, 2015.

60. Manole A., Z. Jaunmuktane, I. Hargreaves, M. H. R. Ludtmann, V. Salpietro, O. D. Bello, S. Pope, A. Pandraud, A. Horga, R. S. Scalco, A. Li, B. Ashokkumar, C. M. Lourenço, S. Heales, R. Horvath, P. F. Chinnery, C. Toro, A. B. Singleton, T. S. Jacques, A. Y. Abramov, F. Muntoni, M. G. Hanna, M. M. Reilly, T. Revesz, D. M. Kullmann, J. E. C. Jepson and H. Houlden. Clinical, pathological and functional characterization of riboflavin-responsive neuropathy. Brain 140: 2820-2837, 2017.

61. Marie S. K. N., S. M. Oba-Shinjo, R. da Silva, M. Gimenez, G. Nunes Reis, J.-P. Tassan, J. C. Rosa and M. Uno. Stathmin involvement in the maternal embryonic leucine zipper kinase pathway in glioblastoma. Proteome Science 14: 6, 2016.

62. Marsh S. E., E. M. Abud, A. Lakatos, A. Karimzadeh, S. T. Yeung, H. Davtyan, G. M. Fote, L. Lau, J. G. Weinger, T. E. Lane, M. A. Inlay, W. W. Poon and M. Blurton-Jones. The adaptive immune system restrains Alzheimer's disease pathogenesis by modulating microglial function. Proceedings of the National Academy of Sciences 113: E1316-E1325, 2016.

63. Martinez-Mir A., A. González-Pérez, J. Gayán, C. Antúnez, J. Marín, M. Boada, J. LópezArrieta, E. Fernández, R. Ramírez-Lorca, M. Saez, A. Ruiz, F. Scholl and L. Real. Genetic Study of Neurexin and Neuroligin Genes in Alzheimer's Disease. 2013. 
64. Massagué J. TGF $\beta$ signalling in context. Nature Reviews Molecular Cell Biology 13: 616, 2012.

65. Matcovitch-Natan O., D. R. Winter, A. Giladi, S. Vargas Aguilar, A. Spinrad, S. Sarrazin, H. Ben-Yehuda, E. David, F. Zelada González, P. Perrin, H. Keren-Shaul, M. Gury, D. LaraAstaiso, C. A. Thaiss, M. Cohen, K. Bahar Halpern, K. Baruch, A. Deczkowska, E. LorenzoVivas, S. Itzkovitz, E. Elinav, M. H. Sieweke, M. Schwartz and I. Amit. Microglia development follows a stepwise program to regulate brain homeostasis. Science 353: 2016.

66. Mitra K., A.-R. Carvunis, S. K. Ramesh and T. Ideker. Integrative approaches for finding modular structure in biological networks. Nature reviews. Genetics 14: 719-732, 2013.

67. Mjelle R., S. A. Hegre, P. A. Aas, G. Slupphaug, F. Drabløs, P. Sætrom and H. E. Krokan. Cell cycle regulation of human DNA repair and chromatin remodeling genes. DNA Repair 30: 5367, 2015.

68. Mostafavi S., C. Gaiteri, S. Sullivan, C. White, S. Takasi, J. Xu, M. Taga, H. Klein, E. Patrick, V. Komashko, C. McCable, R. Smith, E. Bradshaw, D. Root, L. Yu, A. Regev, L. Chibnik, J. Schneider, T. Young-Pearse, D. Bennett and P. De Jager. A molecular network of the aging brain implicates INPPL1 and PLXNB1 in Alzheimer's disease. bioRxiv 2017.

69. Poirier R., H. Cheval, C. Mailhes, S. Garel, P. Charnay, S. Davis and S. Laroche. Distinct Functions of Egr Gene Family Members in Cognitive Processes. Frontiers in Neuroscience 2: 4755, 2008.

70. Recabarren D. and M. Alarcón. Gene networks in neurodegenerative disorders. Life Sciences 183: 83-97, 2017.

71. Rissman R. A., K.-F. Lee, W. Vale and P. E. Sawchenko. Corticotropin-Releasing Factor Receptors Differentially Regulate Stress-Induced Tau Phosphorylation. The Journal of Neuroscience 27: 6552-6562, 2007.

72. Ritchie M. E., B. Phipson, D. Wu, Y. Hu, C. W. Law, W. Shi and G. K. Smyth. limma powers differential expression analyses for RNA-sequencing and microarray studies. Nucleic Acids Research 43: e47-e47, 2015.

73. Rosenthal S. B., J. Len, M. Webster, A. Gary, A. Birmingham and K. M. Fisch. Interactive network visualization in Jupyter notebooks: visJS2jupyter. Bioinformatics btx581-btx581, 2017.

74. Sannerud R., I. Declerck, A. Peric, T. Raemaekers, G. Menendez, L. Zhou, B. Veerle, K. Coen, S. Munck, B. De Strooper, G. Schiavo and W. Annaert. ADP ribosylation factor 6 (ARF6) controls amyloid precursor protein (APP) processing by mediating the endosomal sorting of BACE1. Proceedings of the National Academy of Sciences of the United States of America 108: E559-E568, 2011.

75. Schindowski K., K. Belarbi and L. Buée. Neurotrophic factors in Alzheimer's disease: role of axonal transport. Genes, Brain, and Behavior 7: 43-56, 2008.

76. Schmidt-Edelkraut U., A. Hoffmann, G. Daniel and D. Spengler. Zac1 Regulates Astroglial Differentiation of Neural Stem Cells Through Socs3. Stem Cells 31: 1621-1632, 2013.

77. Settembre C., C. Di Malta, V. A. Polito, M. G. Arencibia, F. Vetrini, S. Erdin, S. U. Erdin, T. Huynh, D. Medina, P. Colella, M. Sardiello, D. C. Rubinsztein and A. Ballabio. TFEB Links Autophagy to Lysosomal Biogenesis. Science (New York, N.Y.) 332: 1429-1433, 2011.

78. Sheng M., B. Sabatini and T. C. Südhof. Synapses and Alzheimer's disease. Cold Spring Harbor perspectives in biology 4: 10.1101/cshperspect.a005777 a005777, 2012.

79. Silva D. F., J. E. Selfridge, J. Lu, L. E, N. Roy, L. Hutfles, J. M. Burns, E. K. Michaelis, S. Yan, S. M. Cardoso and R. H. Swerdlow. Bioenergetic flux, mitochondrial mass and 
mitochondrial morphology dynamics in AD and MCI cybrid cell lines. Human Molecular Genetics 22: 3931-3946, 2013.

80. Sjolander A., L. Minthon, L. Nuytinck, E. Vanmechelen, K. Blennow and S. Nilsson. Functional mannose-binding lectin haplotype variants are associated with Alzheimer's disease. $J$ Alzheimers Dis 35: 121-127, 2013.

81. Strachan G. D., L. A. Ostrow and K. L. Jordan-Sciutto. Expression of the fetal Alz-50 clone 1 protein induces apoptotic cell death. Biochemical and Biophysical Research Communications 336: 490-495, 2005.

82. Subramanian A., P. Tamayo, V. K. Mootha, S. Mukherjee, B. L. Ebert, M. A. Gillette, A. Paulovich, S. L. Pomeroy, T. R. Golub, E. S. Lander and J. P. Mesirov. Gene set enrichment analysis: A knowledge-based approach for interpreting genome-wide expression profiles. Proceedings of the National Academy of Sciences of the United States of America 102: 1554515550, 2005.

83. Tan L., J. T. Yu, M. S. Tan, Q. Y. Liu, H. F. Wang, W. Zhang, T. Jiang and L. Tan. Genome-wide serum microRNA expression profiling identifies serum biomarkers for Alzheimer's disease. J Alzheimers Dis 40: 1017-1027, 2014.

84. Thundyil J., D. Pavlovski, C. G. Sobey and T. V. Arumugam. Adiponectin receptor signalling in the brain. British Journal of Pharmacology 165: 313-327, 2012.

85. Tramutola A., C. Lanzillotta, M. Perluigi and D. A. Butterfield. Oxidative stress, protein modification and Alzheimer disease. Brain Research Bulletin 133: 88-96, 2017.

86. Tramutola A., J. C. Triplett, F. Di Domenico, D. M. Niedowicz, M. P. Murphy, R. Coccia, M. Perluigi and D. A. Butterfield. Alteration of mTOR signaling occurs early in the progression of Alzheimer disease (AD): analysis of brain from subjects with pre-clinical AD, amnestic mild cognitive impairment and late-stage AD. Journal of Neurochemistry 133: 739-749, 2015.

87. van Laarhoven T. and E. Marchiori. Robust Community Detection Methods with Resolution Parameter for Complex Detection in Protein Protein Interaction Networks. In: Pattern Recognition in Bioinformatics: 7th IAPR International Conference, PRIB 2012, Tokyo, Japan, November 8-10, 2012. Proceedings, edited by T. Shibuya, H. Kashima, J. Sese and S. Ahmad. Berlin, Heidelberg: Springer Berlin Heidelberg, 2012, pp. 1-13.

88. Vincent D. B., G. Jean-Loup, L. Renaud and L. Etienne. Fast unfolding of communities in large networks. Journal of Statistical Mechanics: Theory and Experiment 2008: P10008, 2008.

89. von Bernhardi R., F. Cornejo, G. E. Parada and J. Eugenín. Role of TGF $\beta$ signaling in the pathogenesis of Alzheimer's disease. Frontiers in Cellular Neuroscience 9: 426, 2015.

90. Wang J., S. Vasaikar, Z. Shi, M. Greer and B. Zhang. WebGestalt 2017: a more comprehensive, powerful, flexible and interactive gene set enrichment analysis toolkit. Nucleic Acids Research 45: W130-W137, 2017.

91. Wang X.-X., M.-S. Tan, J.-T. Yu and L. Tan. Matrix Metalloproteinases and Their Multiple Roles in Alzheimer\&\#x2019;s Disease. BioMed Research International 2014: 8, 2014.

92. Watabe-Rudolph M., Z. Song, L. Lausser, C. Schnack, Y. Begus-Nahrmann, M. O. Scheithauer, G. Rettinger, M. Otto, H. Tumani, D. R. Thal, J. Attems, K. A. Jellinger, H. A. Kestler, C. A. von Arnim and K. L. Rudolph. Chitinase enzyme activity in CSF is a powerful biomarker of Alzheimer disease. Neurology 78: 569-577, 2012.

93. Weeraratna A. T., A. Kalehua, I. DeLeon, D. Bertak, G. Maher, M. S. Wade, A. Lustig, K. G. Becker, W. Wood, D. G. Walker, T. G. Beach and D. D. Taub. Alterations in immunological and neurological gene expression patterns in Alzheimer's disease tissues. Experimental Cell Research 313: 450-461, 2007. 
94. Weissman L., D.-G. Jo, M. M. Sørensen, N. C. de Souza-Pinto, W. R. Markesbery, M. P. Mattson and V. A. Bohr. Defective DNA base excision repair in brain from individuals with Alzheimer's disease and amnestic mild cognitive impairment. Nucleic Acids Research 35: 55455555, 2007.

95. White C. C., H.-S. Yang, L. Yu, L. B. Chibnik, R. J. Dawe, J. Yang, H.-U. Klein, D. Felsky, A. Ramos-Miguel, K. Arfanakis, W. G. Honer, R. A. Sperling, J. A. Schneider, D. A. Bennett and P. L. De Jager. Identification of genes associated with dissociation of cognitive performance and neuropathological burden: Multistep analysis of genetic, epigenetic, and transcriptional data. Plos Medicine 14: e1002287, 2017.

96. Woody S. K., H. Zhou, S. Ibrahimi, Y. Dong and L. Zhao. Human ApoE varepsilon2 Promotes Regulatory Mechanisms of Bioenergetic and Synaptic Function in Female Brain: A Focus on V-type H+-ATPase. J Alzheimers Dis 53: 1015-1031, 2016.

97. Yu G., L.-G. Wang, Y. Han and Q.-Y. He. clusterProfiler: an R Package for Comparing Biological Themes Among Gene Clusters. OMICS : a Journal of Integrative Biology 16: 284-287, 2012.

98. Yung Y. C., N. C. Stoddard, H. Mirendil and J. Chun. Lysophosphatidic acid (LPA) signaling in the nervous system. Neuron 85: 669-682, 2015.

99. Zhang B., C. Gaiteri, L.-G. Bodea, Z. Wang, J. McElwee, A. A. Podtelezhnikov, C. Zhang, T. Xie, L. Tran, R. Dobrin, E. Fluder, B. Clurman, S. Melquist, M. Narayanan, C. Suver, H. Shah, M. Mahajan, T. Gillis, J. Mysore, M. E. MacDonald, J. R. Lamb, D. A. Bennett, C. Molony, D. J. Stone, V. Gudnason, A. J. Myers, E. E. Schadt, H. Neumann, J. Zhu and V. Emilsson. Integrated systems approach identifies genetic nodes and networks in late-onset Alzheimer's disease. Cell 153: 707-720, 2013.

100. Zhang C., C.-C. Kuo, S. H. Moghadam, L. Monte, S. N. Campbell, K. C. Rice, P. E. Sawchenko, E. Masliah and R. A. Rissman. Corticotropin-releasing factor receptor-1 antagonism mitigates beta amyloid pathology and cognitive and synaptic deficits in a mouse model of Alzheimer's disease. Alzheimer's \& Dementia 12: 527-537, 2016.

101. Zou F., O. Belbin, M. M. Carrasquillo, O. J. Culley, T. A. Hunter, L. Ma, G. D. Bisceglio, M. Allen, D. W. Dickson, N. R. Graff-Radford, R. C. Petersen, G. the, C. Environmental Risk for Alzheimer's disease, K. Morgan and S. G. Younkin. Linking Protective GAB2 Variants, Increased Cortical GAB2 Expression and Decreased Alzheimer's Disease Pathology. Plos One 8: e64802, 2013. 
bioRxiv preprint doi: https://doi org/10.1101/286674; this version posted March 22, 2018. The copyright holder for this preprint (which was not certified by peer review) is the author/funder, who has granted bioRxiv a license to display the preprint in perpetuity. It is made available under aCC-BY 4.0 International license.

A

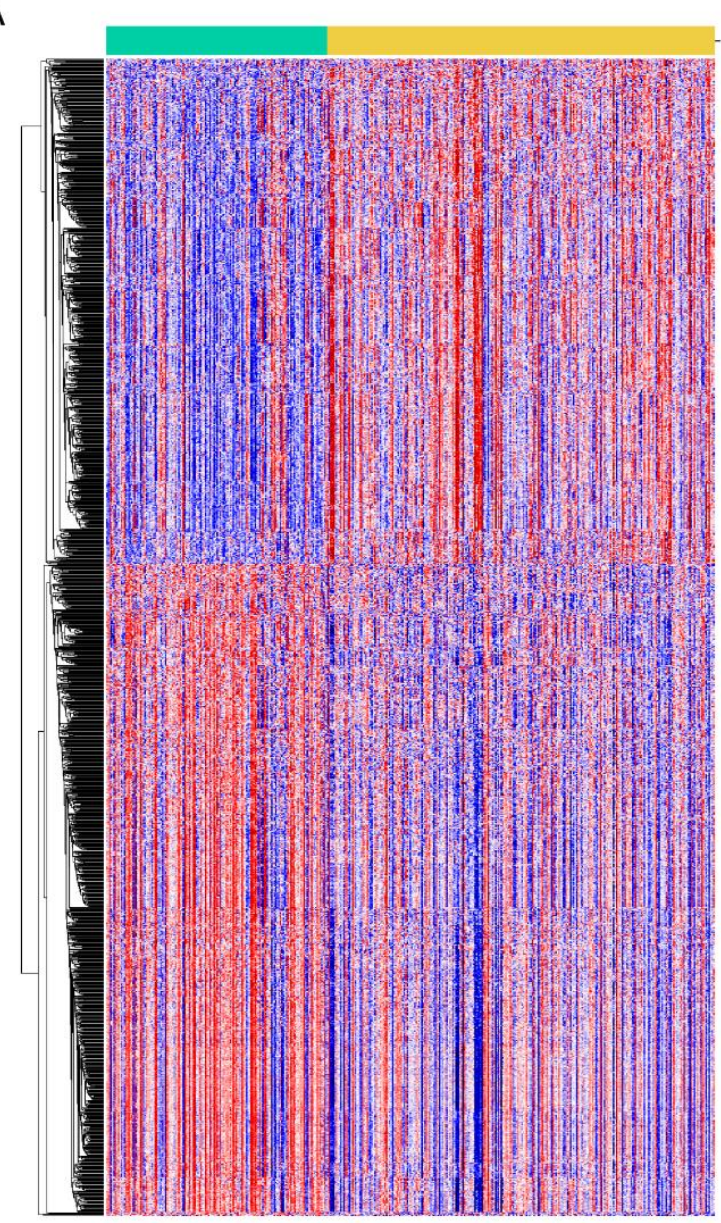

B

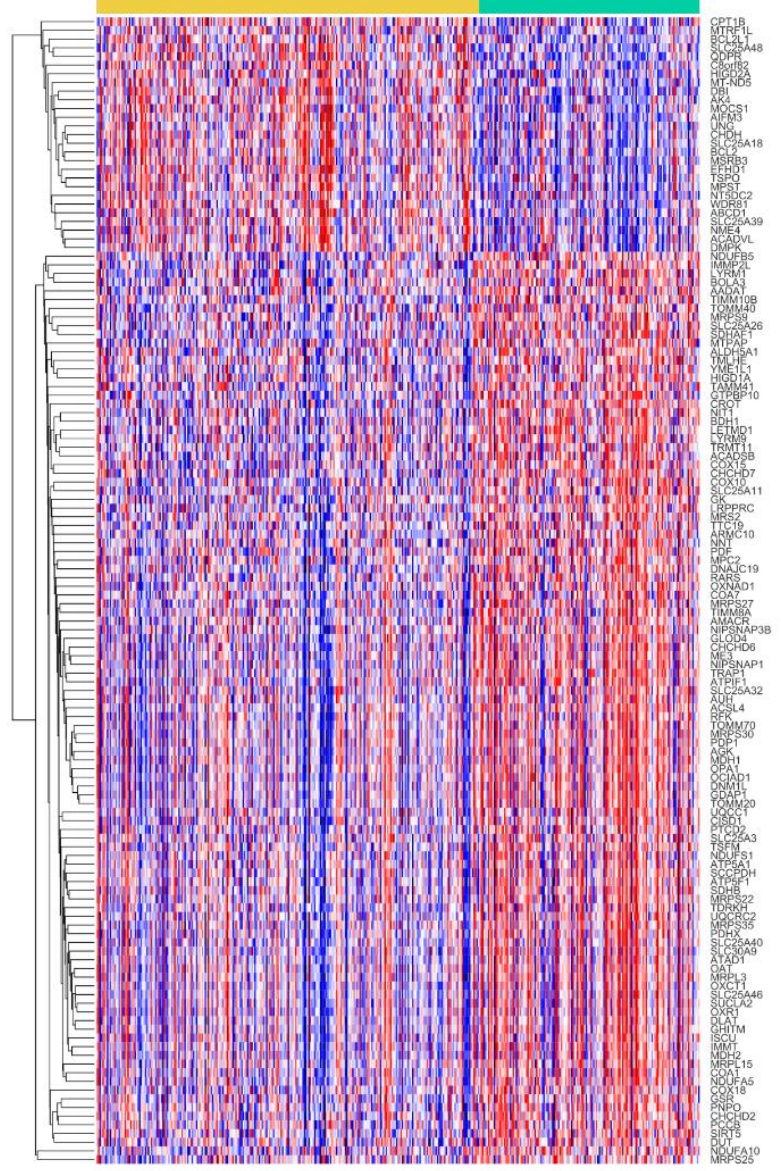

C

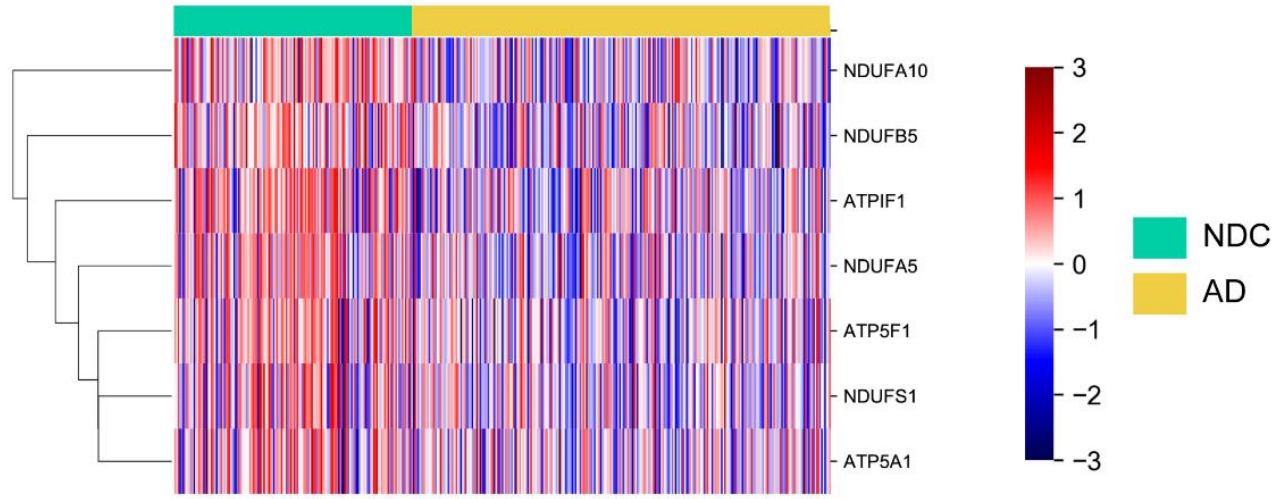

Figure 1 
bioRxiv preprint doi: https://doi.org/10.1101/286674; this version posted March 22, 2018. The copyright holder for this preprint (which was not certified by peer review) is the author/funder, who has granted bioRxiv a license to display the preprint in perpetuity. It is made available under aCC-BY 4.0 International license.

A

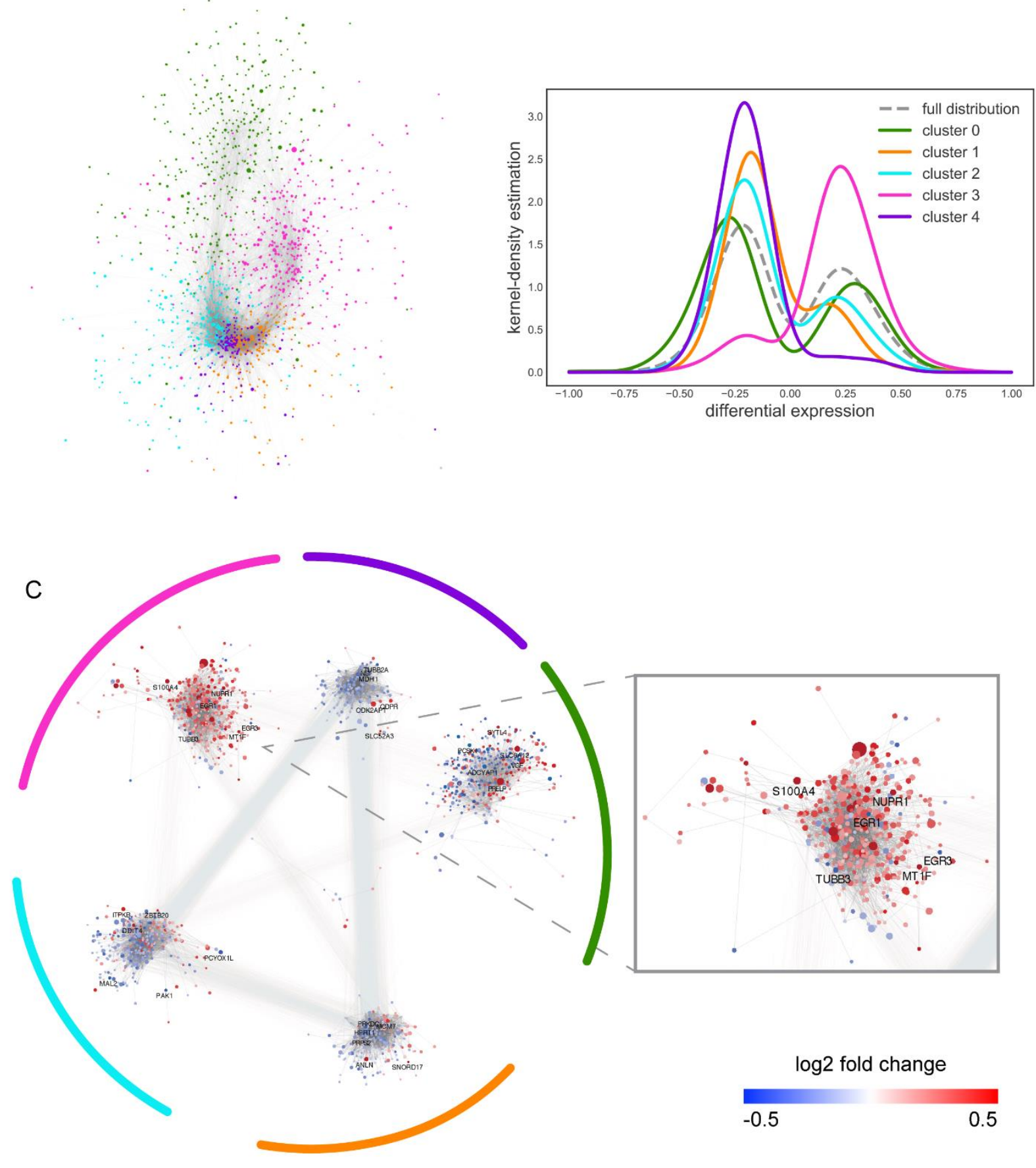

Figure 2 
bioRxiv preprint doi: https://doi org/10.1101/286674; this version posted March 22, 2018. The copyright holder for this preprint (which was not certified by peer review) is the author/funder, who has granted bioRxiv a license to display the preprint in perpetuity. It is made available under aCC-BY 4.0 International license.

A

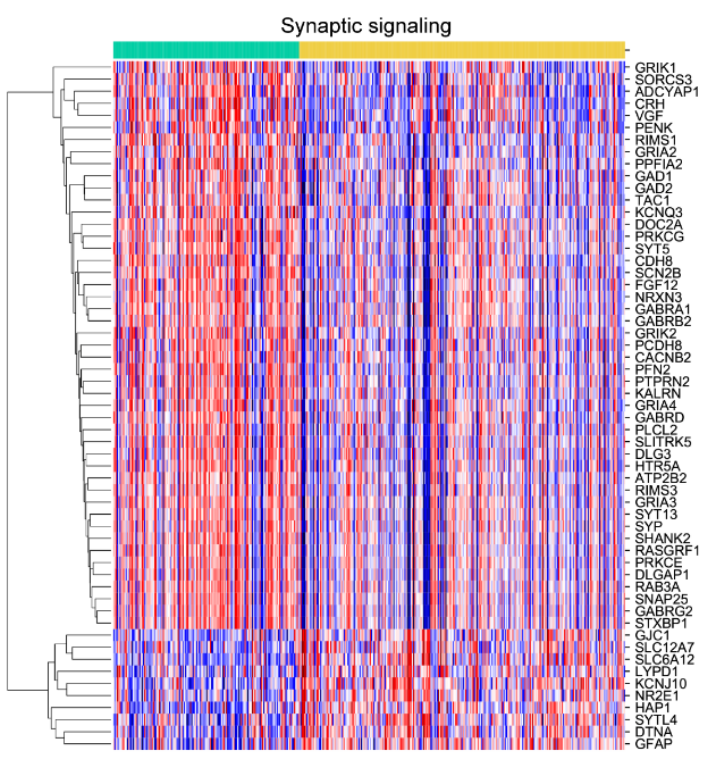

C

\section{Cluster 2}

Immune response-regulating cell surface receptor signaling pathway

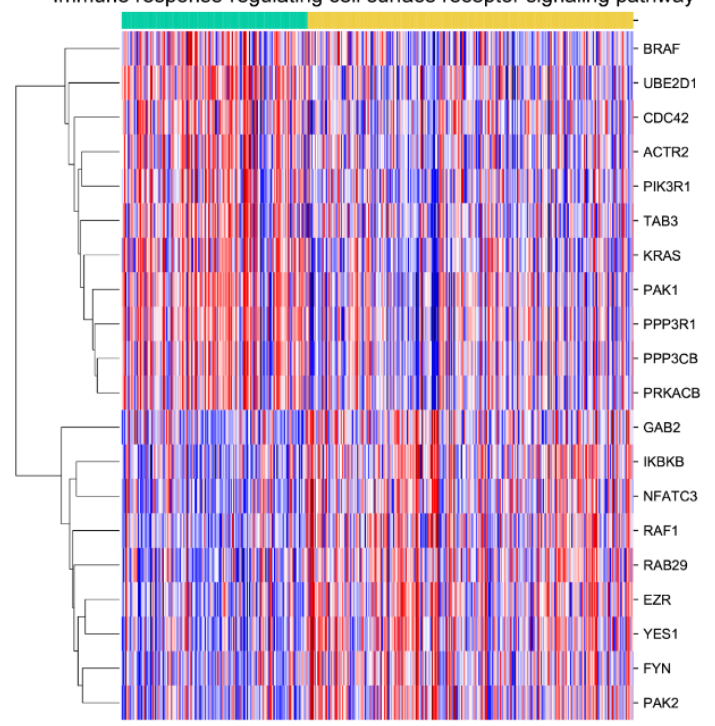

B

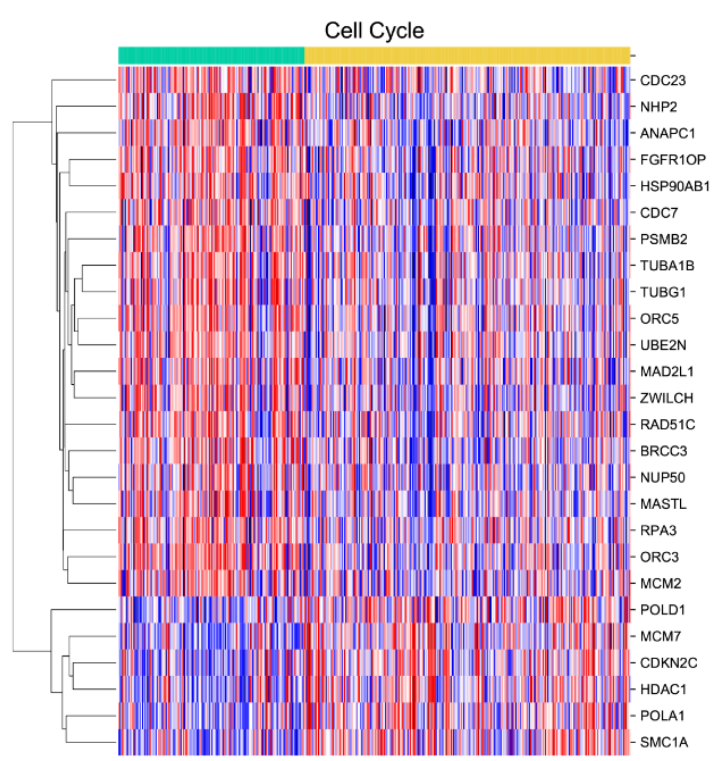

D

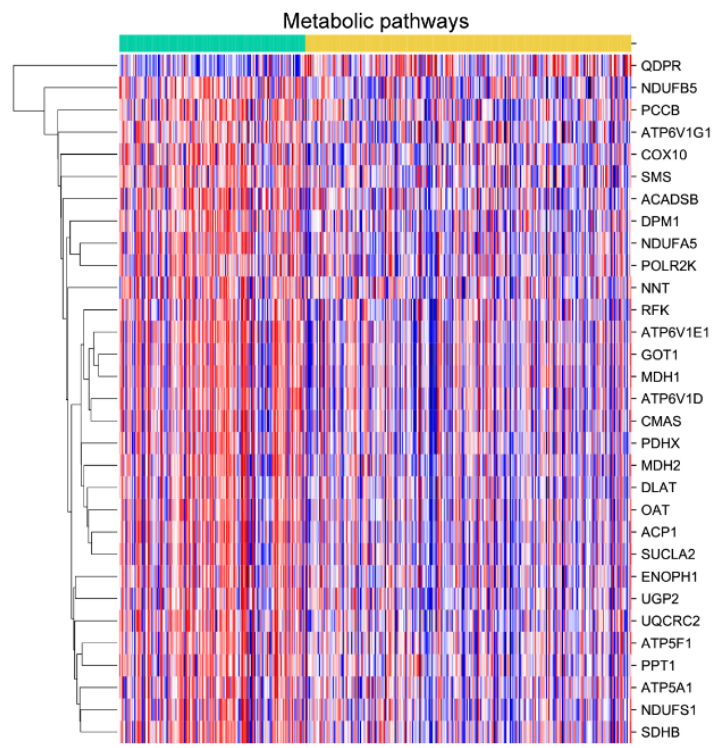

Figure 3 
bioRxiv preprint doi: https://doi.org/10.1101/286674; this version posted March 22 2018. The copyright holder for this preprint (which was not certified by peer review) is the author/funder, who has granted bioRxiv a license to display the preprint in perpetuity. It is made available under aCC-BY 4.0 International license.

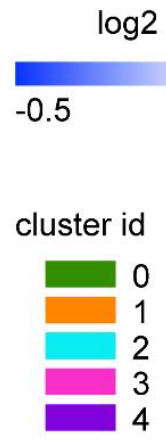
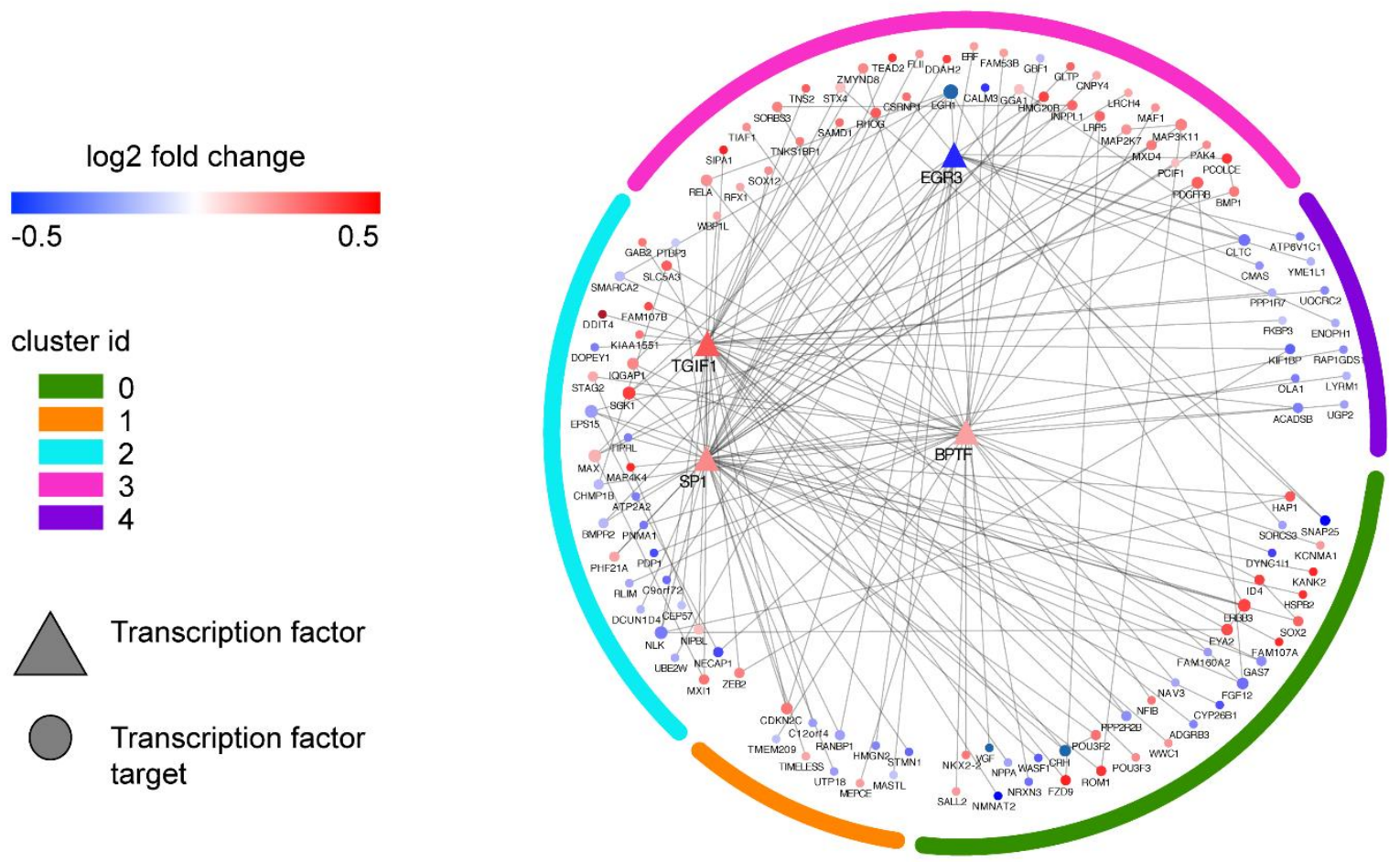

Figure 4 
bioRxiv preprint doi: https://doi.org/10.1101/286674; this version posted March 22, 2018. The copyright holder for this preprint (which was not certified by peer review) is the author/funder, who has granted bioRxiv a license to display the preprint in perpetuity. It is made available under aCC-BY 4.0 International license.

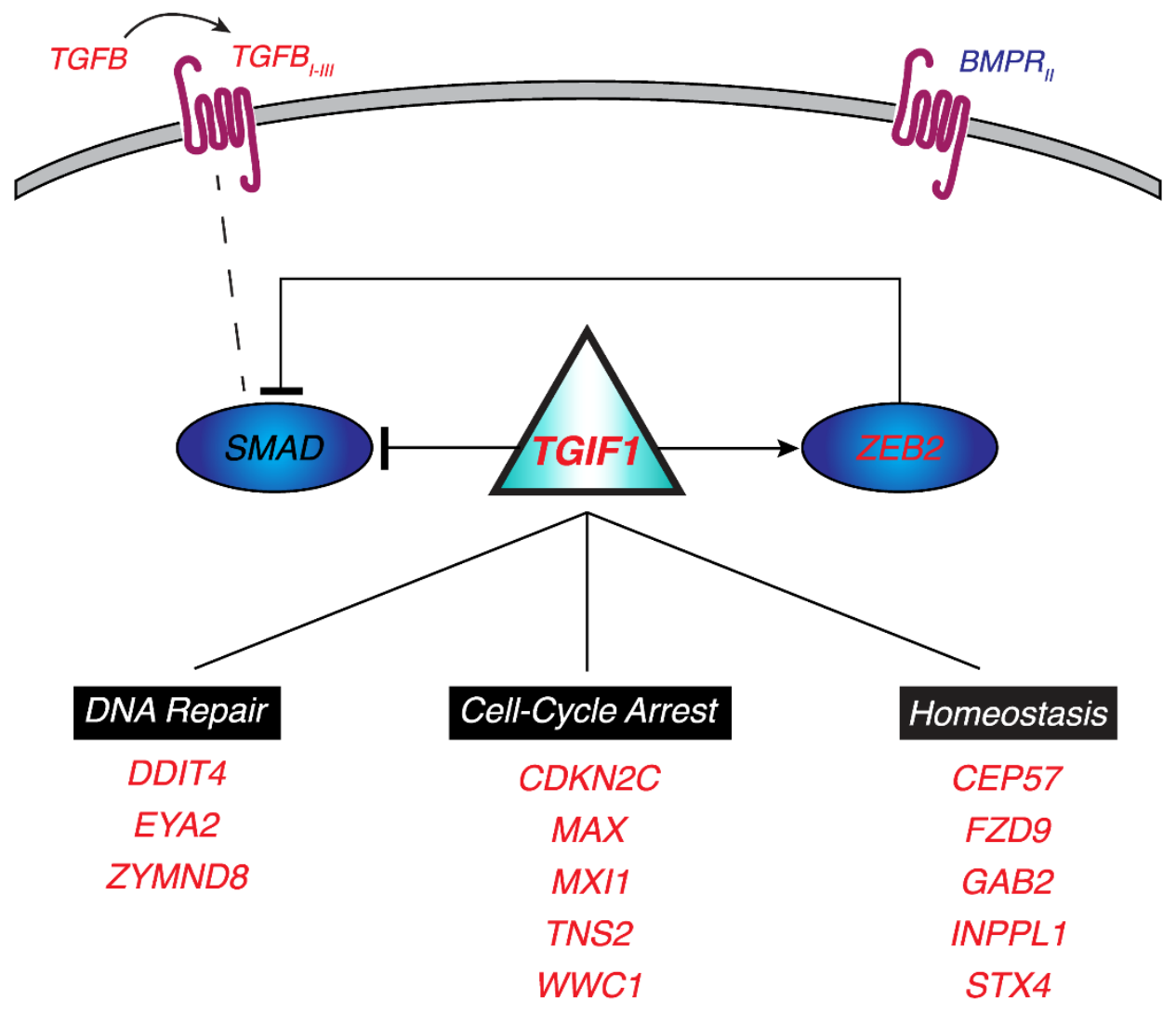

Figure 5 


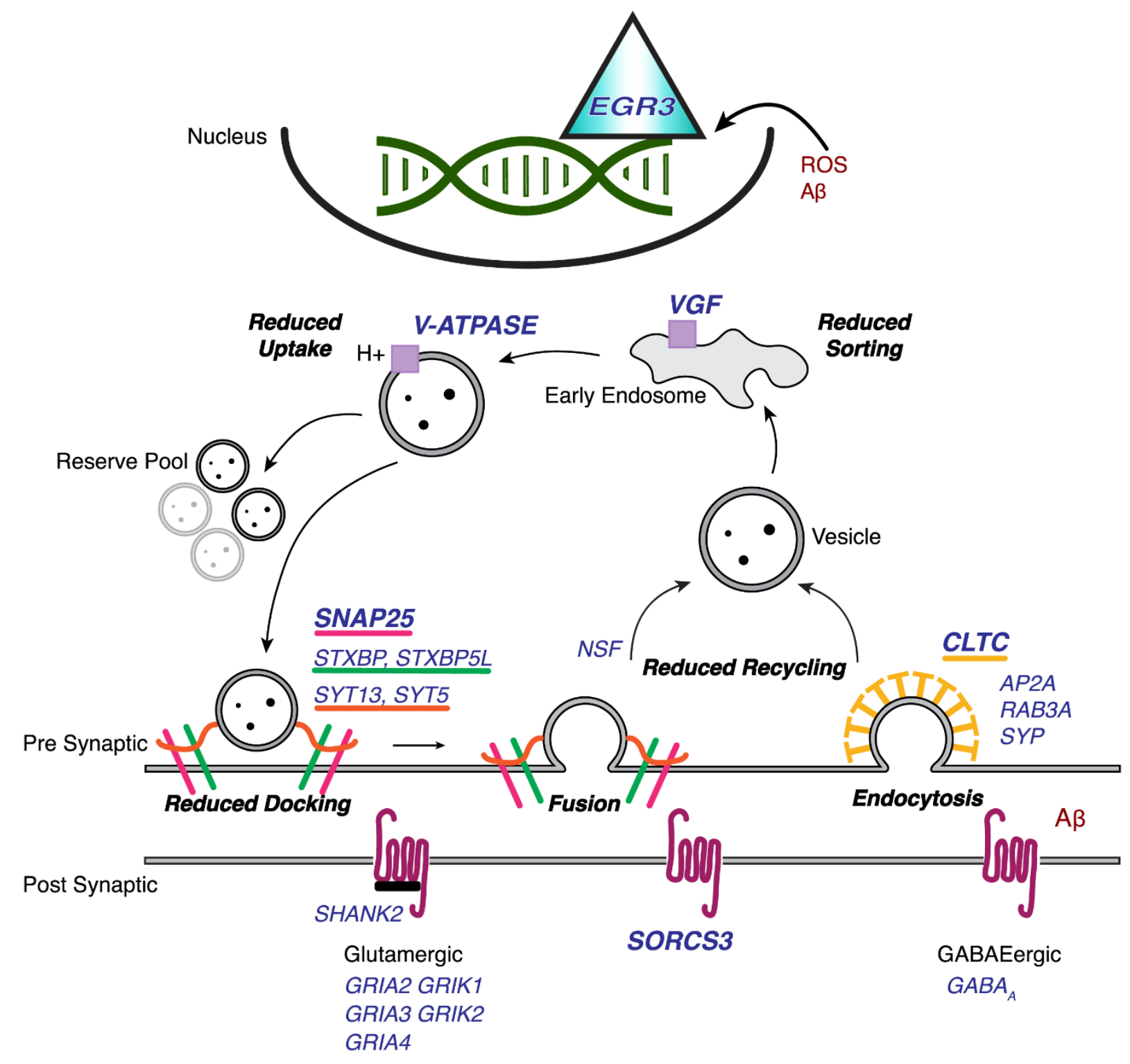

Figure 6 
bioRxiv preprint doi: https://doi.org/10.1101/286674; this version posted March 22, 2018. The copyright holder for this preprint (which was not certified by peer review) is the author/funder, who has granted bioRxiv a license to display the preprint in perpetuity. It is made available under aCC-BY 4.0 International license.
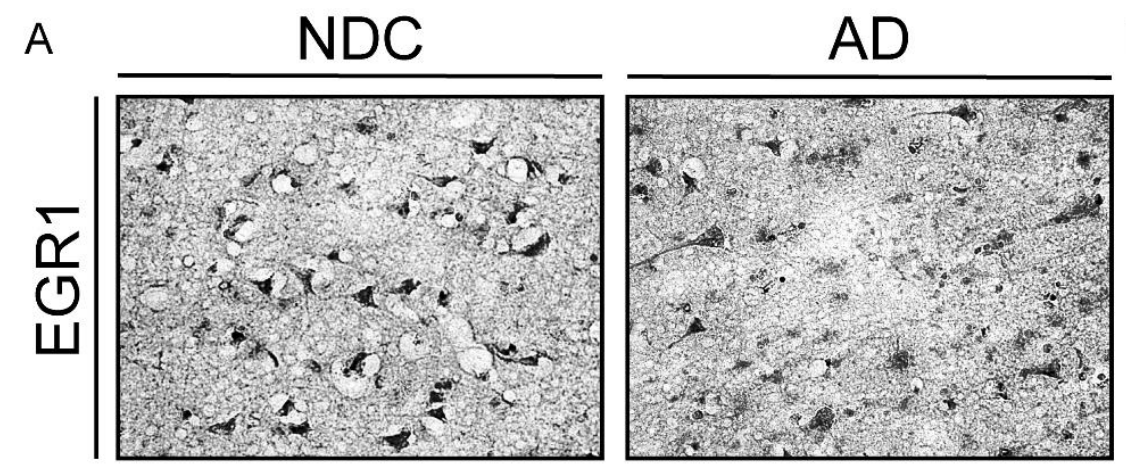

B
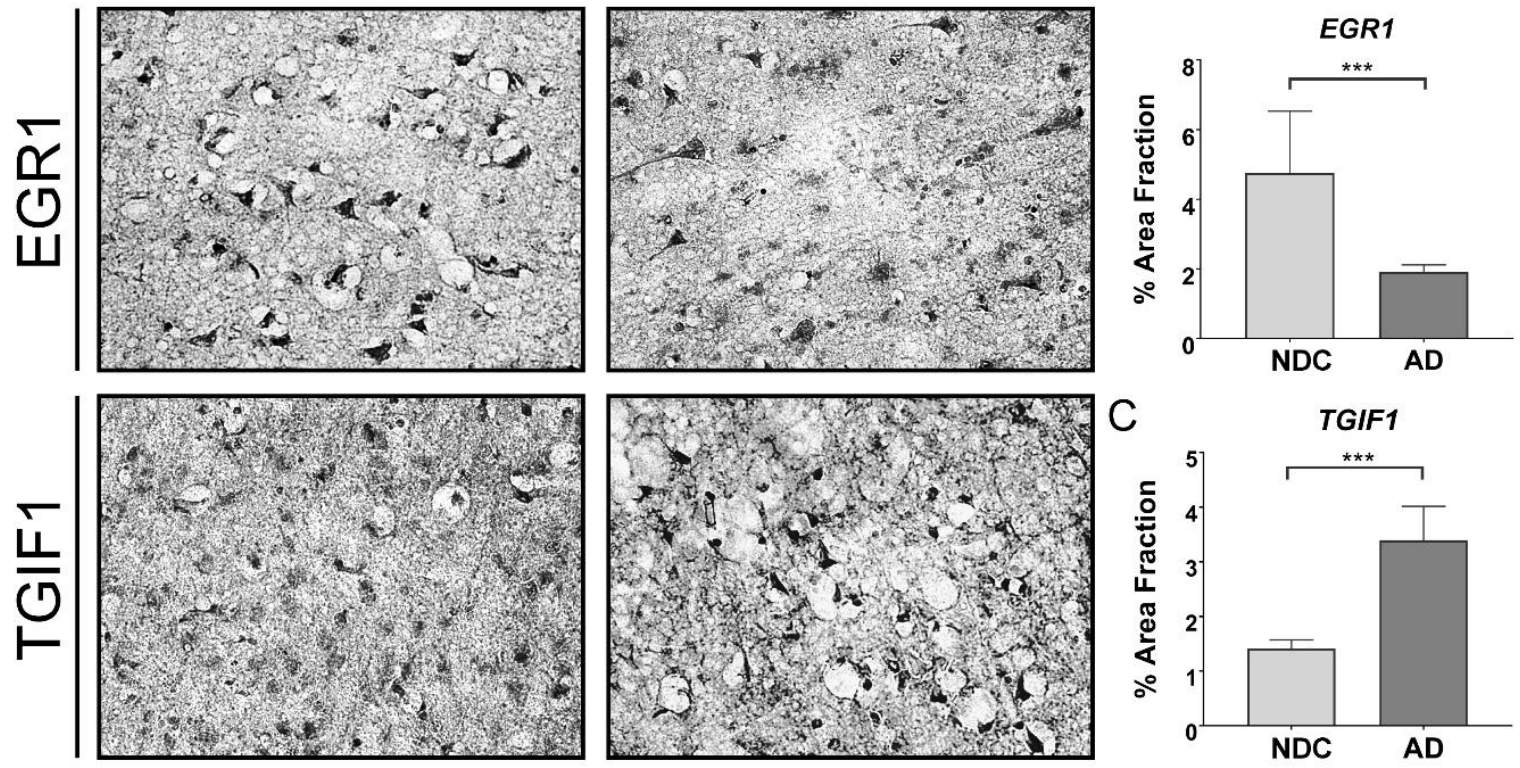

Figure 7 